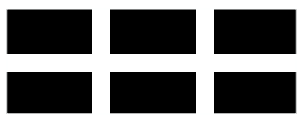

THE WILLIAM DAVIDSON INSTITUTE AT THE UNIVERSITY OF MICHIGAN BUSINESS SCHOOL

The Politics of Development Policy and Development Policy Reform in New Order Indonesia

\author{
By: Michael T. Rock
}

William Davidson Institute Working Paper Number 632

November 2003 


\title{
The Politics of Development Policy and Development
}

\section{Policy Reform in New Order Indonesia}

\author{
Michael T. Rock \\ Professor of Economics \\ Department of Economics and Management \\ Hood College \\ 401 Rosemont Ave. \\ Frederick, MD. 21701 \\ Email:rock@hood.edu \\ Phone: 703-684-7736 \\ (C) Michael T. Rock
}

Paper prepared for Workshop on Policy Reform in Asia

Department of Political Science and William Davidson Institute

University of Michigan 
Ann Arbor, Michigan

September 12, 2002

Revisions completed April 20, 2003

\begin{abstract}
How can we account for Indonesia's astonishing development performance between 1965 and 1997-rapid growth, massive reduction in the incidence of poverty, low income-inequality and substantial diversification of the economy - in the face of extremely dirigiste microeconomic policies, even by developing country standards, and massive, systemic and endemic rent-seeking and corruption? This question is answered by demonstrating that Suharto, the leader of Indonesia's New Order government, was extremely successful in building and sustaining a procapitalist, pro-integration with the world economy, and pro-growth with equity political coalition in which corruption played a central role.
\end{abstract}

Key words: Suharto, New Order, corruption, Indonesia, development policy, economic reform

JEL codes: O53, Q1, F14, N15, N55, N65 


\section{Introduction}

How are we to understand development policy-making and development policy change in Suharto's New Order Indonesia (1965-1998)? It turns out that the answer to this question is dependent on the answer to a more difficult and intriguing question. How could development performance have been so good for so long despite what appears to have been massive, systemic and endemic rent-seeking and corruption (King, 2000 and Robertson-Snape, 1999)? ${ }^{1}$ I begin by outlining the nature of the economic and social achievements of Suharto's New Order government. They were substantial, real, and represent one of three enduring legacies of the Suharto era. ${ }^{2}$ In 1965 the Indonesian economy was in shambles. The economy had more or less stagnated since independence. Between 1960 and 1965 real GDP per capita in a desperately poor Indonesia fell by roughly 10\% (World Bank, 2000). By 1965 inflation was very high (229\%) and accelerating (1,195\% in 1996) (World Bank, 2000). Gross domestic investment was only $6.5 \%$ of GDP and falling (World Bank, 2000). Indonesia's external position was rapidly deteriorating in the face of rampant capital flight while spare parts, raw materials (Winter, 1996: 47), and food were in short supply (Bresnan, 1993: 112). Profitable production had all but ceased (Winter, 1996: 47).

Following a successful macroeconomic stabilization program implemented by the economic technocrats in the new Suharto government, inflation slowed, investment rose, and growth exploded (World Bank, 2000). Between 1966 and 1997, real GDP per capita grew at $5.03 \%$ per year (World Bank, 2000). By 1997 real GDP per capita, which was roughly equal to that in India and China in 1966 (\$960 in India, \$815 in China and \$804 in Indonesia), was 1.6 times India's (\$4114 vs \$2360) and 1.3 times fast growing China’s (\$3058) (World Bank, 2000). Less than a handful of countries grew as fast or faster over this period. Rapid growth went hand in hand with substantial diversification of production, employment, and exports. In 1966 production, employment and exports were concentrated in a small number of agricultural products (rice, coffee, oil palm, and sugar) and natural resources (oil) (World Bank, 2000). Manufactures were less than 10\% of GDP and manufactured exports were non-existent (World

\footnotetext{
${ }^{1}$ Since the 1980s Business International (Mauro, 1995) Transparency International (2002), the World Bank (Kaufmann, Kraay and Loido-Lobaton (1999) and Political Risk Services (Knack and Keefer, 1995) have rated Indonesia as among the most corrupt countries in the world.
} 
Bank, 2000). By 1996, manufactures had risen to more than $25 \%$ of GDP as real manufactured value added increased more than 12 times from $\$ 4.4$ billion to $\$ 57.33$ billion (World Bank, 2000). By 1993, manufactured exports reached $\$ 21$ billion accounting for $53 \%$ of total exports (World Bank, 2000). As a consequence, the share of manufactures in GDP and the share of manufactured exports in total exports were substantially higher than expected and the export concentration index was substantially lower than expected for a country with Indonesia's resource endowment and level of development. ${ }^{3}$

Rapid economic growth and diversification of the economy away from a few primary products was widely shared and poverty reducing. Indonesia's Gini coefficient for household consumption per capita was low at the beginning of its growth miracle (.35 in 1964/65) and it remained low (.36 in 1996) and stable (Booth, 2000: 75). As a consequence, the country experienced a rapid decline in the incidence of poverty and in the absolute number of people who fell below the country's modest poverty line. In 1970, 53.4\% of Indonesia's urban population and 38.7\% of its rural population fell below the poverty line (Booth, 2000: 78). By 1996 only $9.7 \%$ of the urban population and $12.3 \%$ of the rural population remained poor (Booth, 2000: 75). Despite a near doubling of the population from 107 million in 1966 to 200 million in 1996 (World Bank, 2000), the absolute number of poor people fell from 54.2 million to 22.5 million (Booth, 2000: 78).

Rapid shared growth occurred alongside a highly successful green revolution in rice agriculture that led to rice self-sufficiency in 1984 that, until the recent crisis, had more or less been sustained (Booth, 1989). Two decades earlier, this achievement was thought to be virtually impossible (Geertz, 1963). This went hand in hand with one of the world's most successful family planning programs as total fertility fell by more than one-half from 5.57 in 1966 to 2.75 in 1996 (World Bank, 2000). The unprecedented decline in fertility occurred despite substantial initial opposition to it by the country's conservative religious leaders, its traditional birth attendants, many couples, and its former president, who espoused decidedly pro-natalist policies

\footnotetext{
${ }^{2}$ The other enduring legacies of the New Order are its reputation for corruption and its distinctly authoritarian politics.

${ }^{3}$ Following the World Bank (1993), I (1999: 696-696) used a modified Chenery (1979) technique to predict the share of manufactures in GDP, the share of manufactures in total exports, and an export concentration index for 1994. The shares of manufactures in GDP was nearly $20 \%$ larger than predicted, the share of manufactures in total exports was $17 \%$ larger than predicted and the export concentration index was slightly more than $25 \%$ lower than predicted.
} 
(Warwick, 1986: 467). Winning the support of religious leaders and traditional birth attendants was, without doubt, a major victory for the family planning program (Warwick, 1986: 467). Without their active support, it is doubtful that the program would have succeeded. Fertility decline was accompanied by an equally rapid decline in infant mortality (from 124 per thousand live births to 44 per thousand) and a significant rise in life expectancy (from 47 years in 1966 to 67 years in 1997) (World Bank, 2000).

It is unlikely that any of these improvements in social wellbeing would have occurred if the government had not also invested heavily in education, particularly primary education. In 1973, the Suharto government launched a major educational program, Inpres Sekolah Dasar, designed to achieve universal primary education (Warwick, 1986: 462). Between 1973 and 1983 primary school enrollment increased by more than 12 million children and the net primary enrollment ratio rose from $60 \%$ in 1973 to more than $90 \%$ by 1983 (Warwick, 1986: 462). As a consequence, differences in enrollment between rich and poor areas and between boys and girls were nearly eliminated (Warwick, 1986; 462).

Given the performance of the Indonesian economy prior to the New Order and the development performance of all but a handful of other developing countries between 1966 and 1997, Indonesia's development performance during the New Order is nothing short of astonishing. What makes it even more remarkable is that it occurred within the context of what appears to be massive, systemic, and endemic corruption and rent-seeking (King, 2000 and Robertson-Snape, 1999). While it is difficult, if not impossible, to estimate the size of the corruption take in New Order Indonesia, virtually all international surveys of corruption routinely rank Indonesia as among the most corrupt countries in the world (Mauro, 1995; Transparency International, 2002; Kaufmann, Kraay and Zoido-Lobaton, 1999; and Knack and Keefer, 1995). Recent surveys of ordinary Indonesians reveal that a majority (78\%) say they pay bribes when routinely interacting with government officials (Robertson-Snape, 1999: 589). Bribes are paid to register the birth of a child, when applying for a driver's license or marriage certificate, or when applying for a mandatory identity card (Robertson-Snape, 1999: 589).

This petty corruption is almost assuredly dwarfed by the institutionalization of large-scale corruption within government and between government officials and favored businessmen. Within government, large off-budget expenditures in several parastatals, particularly in 
Pertamina, the state oil company, but also in Perhutani, the state forestry company, and in Bulog, the state food logistics agency (MacIntyre, 2000) nearly precipitated at least one major economic collapse (Bresnan, 1993: 164-193). Patron-client relationships between a small number of SinoIndonesian entrepreneurs and a small number of government officials led to a wholesale looting of Indonesia's forests (Barr, 1998). To make matters worse, government officials in the Ministry of Trade and Industry and the State Secretariat routinely used patron-client relationships to grant cronies, including the president's children, monopoly access to particular markets, and favored access to government contracts, promotional privileges and subsidized credit from state-owned banks (Elson, 2001: 194-201 and 250-253). Critics (Dehanani, 2000, Aswicahyono, Hill and Basri, 2000 and Hill, 1996a) contend that systematic corruption contributed to a weak and shallow manufacturing sector suffering from low productivity, over-concentration in the hands of a few, a shallow base, over dependence on imports, and an inability to absorb, adapt or develop new process or production technologies. Despite these criticisms, there is evidence of substantial productivity growth in industry (Timmer, 1999).

The combination of such an astonishing development performance in the face of massive corruption leaves us with a heretofore, large, important and unanswered question. How could development performance have been so good for so long? My central thesis is that one can not understand development policy-making or the development policy changes that facilitated such rapid shared growth in the Suharto government without recognizing how extremely successful Suharto was in building and sustaining a pro-growth with equity political coalition in which corruption played a central role. My argument proceeds in stages. To begin with, I provide a broad outline of a more conventional interpretation of development policy-making and development policy change in New Order Indonesia. This is followed by an alternative that places successful selective interventions in a wide range of markets and corruption at the center of development policy-making and policy change. I close with a few thoughts on the implications of the New Order's political economy of shared growth.

\section{The Neo-liberal View of the Political Economy of the New Order}

The conventional interpretation (Hill, 1996a, MacIntyre, 1993, 1994 and 2000 and Winters, 1996) of development policy-making and development policy reform in New Order Indonesia places Suharto at the center of a long-standing tension between Western trained 
economic technocrats who supposedly favored a neo-liberal approach to development policy and patrimonalists who supposedly favored an interventionist rent-seeking political program. In this view, the technocrats controlled macroeconomic policy writ large - the budget, monetary policy and the exchange rate-while the partimonialists more or less controlled microeconomic policies and the state's micro agencies - including, among others, Perhutani, Pertamina, the Ministry of Industry and Trade, state banks, Bulog, and the State Secretariat.

As a consequence of this bifurcation of development policy-making, development policies in New Order Indonesia were quite paradoxical. At the macroeconomic level, the economic technocrats in the Ministry of Finance, the central bank (Bank of Indonesia) and the national planning agency (BAPPENAS) kept inflation low, successfully managed the exchange rate, and responded quickly and successfully to positive and negative economic shocks. Except for their response to the currency crisis of 1997, macro policy could not have been better (Hill, 1996; Sachs and Warner, 1995; Little, et al, 1993 and Gelb and Associates, 1988). Things could not have been more different at the micro level. Patrimonialists in Perhutani systematically looted Indonesia's forests while their counterparts in Pertamina and Bulog relied on large offbudget expenditures to finance a range of development activities and reward Suharto's supporters. ${ }^{4}$ The patrimonialists also used selective interventions in trade and investment policies, market access policies, credit allocation, and control over government contracts to build cozy rent-seeking relationships between themselves and a small number of cukong entrepreneurs - Sino-Indonesian businessmen who traded a share of their profits for political protection and rents (Elson, 2001: 194-201, 280-281 and 287-288). Over time, this pattern was extended to the president's children (Elson, 2001: 248-250).

By developing country standards, the microeconomic policies in New Order Indonesia were exceedingly dirigiste, particularly when it came to competition. A state oil and gas company held a monopoly on oil and gas development and distribution (Bresnan, 1993: 164193). A state telecommunications company controlled fixed line call business. A state logistics company controlled the distribution of basic commodities (Bresnan, 1993: 125-129). One wellknown crony capitalist held a monopoly on flour milling and trade in cloves (Elson, 2001: 252). Another controlled much of the logging and plywood industry (Barr, 1998). The president's

\footnotetext{
${ }^{4}$ MacIntyre (2000) provides a good look at off-budget expenditures in the New Order.
} 
children were engaged in banking, real estate, telecommunications, shipping, a national car project, toll roads, highways, and power stations (Elson, 2001: 248-250).

Given this bifurcation in development policy, how did Indonesia do so well for so long, particularly since these kinds of micro policies normally reduce growth and investment, undermine the legitimacy of governments, and spark substantial and prolonged debt crises?

Why did this not happen in Indonesia? The neo-liberal answer is that this did not happen because Suharto favored the patrimonialists and their rent-seeking political program during periods of economic expansion but reined them in during hard times (Liddle, 1991: 419-420; Woo, Glassburner and Nasution, 1994: chapter 9 and Gillis, 1984: 244, 250-251). There is some truth to this answer. When inflation rose, as it did in 1966 and 1997/98, Suharto turned to his technocrats who implemented traditional macroeconomic stabilization programs. ${ }^{5}$ When patrimonial polices, particularly excessive borrowing by Pertamina, threatened Indonesia's credit rating in world markets, Suharto turned again to his technocrats who eliminated Pertamina's ability to borrow in international capital markets while resolving a looming debt crisis (Bresnan, 1993: chapter 3 and Winters, 1996: 84-90). And when the economy slowed, as it did following the failures in second stage import substitution and the fall in oil prices in the early 1980s, Suharto turned once again to his technocrats (Bresnan, 1993: chapter 10). They responded by liberalizing the trade and investment regimes, simplifying the system of promotional privileges offered by the country's investment promotion agency, contracting out the country's custom services, and de-regulating the financial system (Bresnan, 1993; chapter 10 and Winters, 1996: 155-180).

In each instance, implementation of neo-liberal policies had the desired effects-inflation slowed, growth increased, export earnings rose, and potentially serious debt crises were resolved. Taken together, the reliance on the technocrats during hard times alongside minimal opportunities for corruption and rent-seeking in macroeconomic policies limited the damage to the economy by the patrimonialists. As a result, Indonesia was able to grow rapidly, reduce the incidence of poverty, keep income inequality low while reaping the benefits of participating in global trade and investment despite the regime's dirigiste microeconomic policies. Because of this, neo-liberals attribute Indonesia's long run developmental successes to sound 
macroeconomic management, openness to world markets, and limited price distortions (World Bank, 1993, World Bank, 1983 and Hill, 1996). They attribute its failures in forestry, second stage import substitution, industrial policy, and its inflation, debt, and financial cum currency crises to state intervention in micro-economic markets that served patrimonial rent-seeking functions in the context of crony capitalism (Krugman, 1998; Barr, 1998; MacIntyre, 1994; Hill, 1996; Gillis, 1988).

This is an internally consistent and, in its own terms, compelling argument. But there are several problems with it. To begin with, the focus on the longstanding tension between Suhartos' technocrats who supposedly favored neo-liberal development policies and his patrimonialists who supposedly favored a rent-seeking political agenda, is a half-truth at best. Such a view overestimates the degree to which the technocrats were unbridled supporters of neoliberal development policies and foreign investment. ${ }^{6}$ It also underestimates the degree to which Suharto was committed to a shared growth development agenda. ${ }^{7}$ It conflates a longstanding tension between the technologists, sometimes referred to as the economic nationalists, in the New Order government, who favored a Japanese and more state-centered approach to economic development and the patrimonialists (Liddle 1991 and Pangaribuan, 1995). It confuses the patrimonialists within state-owned enterprises such as Pertimina and those in the State Secretariat who favored pribumi entrepreneurs (Pangaribuan, 1995). It underestimates the degree to which Suharto used the patrimonialists in government to build and sustain support for his regime and his development policies while he and they tamed political opposition in civil society (Pangaribuan, 1995).

It also offers an inadequate explanation for the failure of massive rent-seeking and corruption to slow growth. While the neo-liberals are essentially correct that rent-seekers were

\footnotetext{
${ }^{5}$ For discussion of the stabilization program of the 1960s see Hill (1996: 30-35) and Bresnan (1993: chapter 3). For discussion of the technocrats' response to the currency cum financial crisis of 1996/7 see Pincus and Ramli (1998).

${ }^{6}$ Several prominent technocrats have expressed the need to overcome the legacy of colonialism or Indonesia's dual ekonomie kolonial. One, Professor Salim, stated that the desire to guide the economy and eliminate liberalism (unfettered markets) emerges from the experience of colonialism when, "... the people suffered much from economic liberalism ..." (Glassburner, 1978a: 30). Another, Professor Widjojo, attributed Indonesia's low income and income inequality to the operation of market forces. Because of this, he advocated sustained control over the volume and direction of investment to avoid structural debilities (Glassburner, 1978a: 31). The technocrats have also supported an "appropriate level of economic nationalism" cum industrialization (McCawley, 1982: 103). Despite this, it is curious that neo-liberals have not seen fit to grant any coherence or influence to selective interventions on economic outcomes. ${ }^{7}$ See discussion on pp. 12-14.
} 
not able, until recently, to ransack either the treasury ${ }^{8}$ or the central bank ${ }^{9}$, there is little doubt that they exerted substantial influence over micro policies. This enabled them to loot Indonesia's forests and earn monopoly profits on a wide range of consumer products - from toll roads, to clove cigarettes, to noodles, to flour milling, and automobiles. It also enabled them to invest in costly capital-intensive projects such as steel, automobile manufacture, and aircraft. There is also little doubt that the microeconomic distortions in New Order microeconomic policies thwarted competition, rewarded cronies, and encouraged substantial investment in uneconomic projects. Until the collapse of the New Order in 1998, few of these activities were ever significantly constrained or eliminated by the technocrats' neo-liberal reforms (Robinson, 1992: 72 and Pincus and Ramli, 1998: 728). Yet none of this appears to have slowed growth? Why? As of yet, there is no good answer to this question.

But even if the neo-liberals are, at least partially correct, their interpretation does not quite explain why the economy collapsed all at once in 1997 from rent-seeking and crony capitalism? Nor does it help us understand the poor macroeconomic policy response to the financial cum currency crisis (Pincus and Ramli, 1998), or the apparent politicization of the core macro agencies in Indonesia in the late 1990s. Moreover, neo-liberal analysis comes at the cost of ignoring how corruption and rent-seeking may have been growth enhancing. ${ }^{10}$ It also comes at the cost of overestimating the bifurcation in the New Order state between macroeconomic and microeconomic policymaking (Rock, 1999: 694). As a consequence, it overlooks several notable instances where the technocrats intervened in micro markets to good effect. It also comes at the cost of failing to understand the deep-seated mistrust of markets and foreign investment in Indonesia, and the desire of Indonesians, of all political persuasions, to overcome Indonesia's ekonomie kolonial and replacing it with a strong, diversified, and industrialized economy-or ekonomie nasional (Chalmers and Hadiz, 1997: 6-8 and 71-75).

\footnotetext{
${ }^{8}$ In September an audit by the State Development Finance Committee concluded that Rp 10.3 trillion of state funds had been misused, Rp 1.3 trillion disappeared from the Ministry of Finance (Siregar, 2001: 299).

${ }^{9}$ In 2001, external audits of the central bank found significant irregularities in the bank's liquidity assistance during the financial crisis (Hamilton-Hart, 2001: 71). Subsequently, the governor of the central bank was arrested on corruption charges and his replacement stated that the bank was little more than a 'den of thieves' (Hamilton-Hart, 2001: 76).

${ }^{10}$ For theoretical and empirical analyses of how corruption can be growth enhancing see Rock and Bonnett (2003) Khan and Jomo (2000), Khan (1996), Wedeman, (1997) and Kang (2002).
} 


\section{Reconstructing the Politics of Development Policy in New Order Indonesia}

How can we combine these fundamental elements-longstanding pursuit of macroeconomic stability, heavy, continuing and abiding government intervention in the microeconomy and pervasive corruption and rent-seeking - of the New Order's political economy into a coherent model of shared growth? It turns out that doing so requires making a small number of, what I hope to demonstrate, are extremely reasonable assumptions. I begin with the assumptions, demonstrate why they are reasonable, and use them to build a political model of shared growth. The assumptions and justification for them are:

1. Political elites in Indonesia, including President Suharto, have been deeply committed to nationalist and developmentalist agendas.

The political elites that came to control the government in Indonesia have been keenly interested in increasing national power in a world dominated by the West. For them development is an important component of national power, a goal in its own right, and a vehicle for consolidating and sustaining their own political regimes. In Indonesia, national unity, national solidarity, and national power have been viewed by political elites of all stripes - from Mohamed Hatta to Sukarno, and Suharto as critical to Indonesia's survival as a nation state (Pabottingi, 1995: 230-232 and Liddle, 1991: 408). Hatta explicitly attributed Indonesia's subjugation at the hands of the Dutch to the lack of national unity, solidarity, and power as the opposite-divisiveness within Indonesia-made exploitation possible (Pabottingi, 1995: 231). Sukarno enshrined national unity in the five principles - or Pancasila - that form the moral basis for political legitimacy in Indonesia (Pabottingi, 1995: 224 and 232). For Suharto, a powerful state is needed to "...maintain independence in a hostile world" (Liddle, 1991: 409) and his commitment to development is based on a hope that it will help create an industrialized and powerful Indonesia (Liddle, 1991: 415). There is also little doubt that Suharto and his supporters rested his legitimacy on the twin pillars of economic development and political stability, both of which have helped ensure the survival of the nation (Pabottingi, 1995: 225). ${ }^{11}$

\footnotetext{
${ }^{11}$ Suharto's commitment to economic development appears to have been largely instrumental. He saw it as a means to achieve political stability. This has been traced to his experiences as a military commander in Central Java. Elson (2001: 60) claims that it was here that Suharto began to realize that economic development might be necessary to ultimately quell the influence of the PKI. And it was here that he also began the practice of raising informal finance for development (Elson, 2001: 60-64). Subsequently, he became the 'father' of Indonesia's development (Elson, 2001: 235). As Elson (2001: 175) says Suharto's commitment to development was so strong that it was, “... a numbingly recurring theme in the multitude of speeches he delivered..."
} 
But economic and industrial development and growth of an indigenous bourgeoisie, in its own right, have been just as important as national unity and national power. As early as 1930, the negative impact of colonialism in Indonesia was defined in terms of the weakening of an indigenous artisan, manufacturing and trading class, the supplanting of an indigenous middle class by the Chinese, and the disintegration of the indigenous economy (Pabottingi, 1995: 230). By the time of independence, Indonesian political elites had articulated a vision of an ekonomie nasional characterized by increasing incomes, economic diversification, and transfer of ownership to indigenous Indonesians (Chalmers and Hadiz, 1997: 8). Indonesians even created a new word, pembangunan, loosely translated as 'development' or “... building, uplifting, and awakening..." (Chalmers and Hadiz, 1997: 1) that “... provides the discourse within which public figures in Indonesia must operate" (Chalmers and Hadiz, 1997: 2). As they say, Suharto and his supporters have sought legitimacy in this term (Chalmers and Hadiz, 1997: 3), by among other things, using it to justify state intervention in the economy and to castigate opponents of the regime as anti-pembangunan (Chalmers and Hadiz, 1997: 4). As Liddle (1991: 413) says, given this, it is not particularly surprising that Suharto viewed economic (and industrial) development - particularly one built on capitalism ${ }^{12}$ — as a national imperative.

2. The New Order government was staunchly pro-capitalist, pro-private property, and, just as staunchly, anti-socialist and anticommunist.

As is well known, Suharto took power following an abortive coup fostered by the Indonesian communist party, the PKI, that resulted in a military-inspired pogrom against the party and a purge of left leaning military and government officials (Bresnan, 1993: chapter 1). His initial base of support came from the politically conservative military, the indigenous (pribumi) business community, landowners, and from an equally conservative (but liberalminded) student population (Chalmers and Hadiz, 1997: 18). Until his downfall in 1997, his government was vigilant in suppressing all elements of the Indonesian left (Elson, 2001: 60, 123127, and 176-177). Even though his government flirted, off and on, with a large state owned

\footnotetext{
${ }^{12}$ Liddle says (1991: 415-416) that Suharto was aware of the gap between the economy as of the early 1990s and that envisaged by the 1945 constitution. Thus he was aware of the strength of the Sino-Indonesian business community and the weaknesses of pribumi business and cooperatives. And he justified his support for the cukong entrepreneurs by the need to follow rational economic laws, which require an emphasis on the private sector. He also appeared to think that most others failed to see that the 1945 constitution did not require state-owned enterprises, but it did require the ability of government to control the private sector.
} 
sector $^{13}$, for most of the New Order, the government favored a capitalist and private enterprise approach to development. But this did not translate into a laissez faire, or free flight liberalism, approach to industrial development and the private sector. This was because political, military, and technocratic elites in Indonesia deeply mistrusted markets and foreign investment. They thought both were responsible for the extreme dualism and poverty of Indonesia. For them, the ultimate challenge facing Indonesia was to overcome Indonesia's 'ekonomie colonial' by using the power of the state to create a strong, integrated, diversified and outward oriented industrial economy or 'ekonomi nasional' owned and operated by an Indonesian bourgeoisie.

Initially, the government promoted an indigenous capitalist class by offering tariff protection to politically favored pribumi entrepreneurs, but because efforts to promote pribumi enterprises failed, government policy soon shifted to supporting a small number of cukong entrepreneurs (Robison, 1986: 41-47 and 133-144). Bias in government policies toward what were to become large Sino-Indonesian capitalist conglomerates went well beyond tariff protection. Those firms were granted preferential access to lucrative monopoly licenses and government contracts. They received preferential access to subsidized credit offered by state owned commercial banks. Government requirements for promotional privileges — such as Board of Investment (BKPM) business tax exemptions on imported capital goods and raw materials and tax holidays also favored a small number of private sector firms. Preferential access to promotional privileges and subsidized credit were frequently combined with bans on new entry into promoted industries and removal of banned industries from eligibility for promotional privileges. One consequence of this package of policies has been the domination of Indonesian industry by large private sector firms combined into a small number of family-centered conglomerates. By the mid-1980s, 55\% of all non-oil manufacturing firms were in industries where four firms accounted for $40 \%$ or more of all sales of an industry (Hill: 1996: 167). ${ }^{14}$ By the mid-1990s, four firm concentration ratios were about $75 \%$ in more than one-half of all industrial sub-sectors (Dehanani, 2000: 122).

3. The New Order government vigorously repressed and controlled popular groups (workers, farmers, students) in civil society and opposition political parties. This

\footnotetext{
${ }^{13}$ Liddle (1991: 416) argues that this reflected the influence of what he called the 'nationalists' - those committed to rapid technological development — on Suharto.

${ }^{14}$ Because Indonesian firms are conglomerated across industries, this understates the degree of seller concentration. Some of these "firms" such as the Salim Group are enormous. In 1992 its sales totaled 20,000 billion rupiah accounting for nearly 20\% of sales of the largest hundred business groups in Indonesia (Sato, 1993: 409).
} 
enabled them to attain and sustain autonomy from both popular groups and opposition political parties. This facilitated implementation of development policies and, in the case of industrial development, facilitated the development of strong growth and corruption oriented relationships between government officials and a small number of cukong entrepreneurs.

Suharto's New Order government has been particularly effective at repressing and controlling popular groups in civil society in Indonesia. Repressive security organizations in the New Order state initially focused on rooting out communists, leftists and supporters of President Sukarno, but over time the repressive apparatus of the state has been turned against others, particularly students, politically organized Islamic organizations, and opposition political parties (Liddle, 1985: 75). Dissident student groups have been routinely disbanded and their leaders arrested (Liddle, 1985: 76). Politically oriented Muslim organizations have been tightly controlled and ultimately forced into one political party (Liddle, 1985: 76). Neither ARBRI, the armed forces, nor the security organizations of the New Order state have been above using fear, intimidation, and outright murder against presumed opponents (Mackie and MacIntyre, 1994: 24). ${ }^{15}$ Until recently, the security apparatus retained the right to arrest and indefinitely hold individuals suspected of subversive activity (Liddle, 1985: 73).

But the New Order government has relied on more than force and fear to control civil society. It has developed an impressive array of softer forms of control. The highly centralized New Order bureaucracy, which is dominated by the Army (ARBI), is visible in every province, district, and village in Indonesia as both the largest employer and the provider of an impressive array of services from schools, health centers, agricultural extension and religious affairs offices (Liddle, 1985: 71). The government has not shied away from using this presence to reward supporters and punish opponents (Mackie and MacIntyre, 1994: 3). Government officials, including local government officials, have been favored by salary increases and stable rice prices; farmers by subsidized fertilizers, seeds, and irrigation water; local rural political officials by INPRES grants for village construction projects (Liddle, 1985: 78).

The government has also more or less organized civil society into a set of functional groups that have been brought together in a quasi-political party, GOLKAR, designed to turn out 
the vote for Suharto and other New Order politicians (Mackie and MacIntyre, 1994: 12). Labor unions, farmer organizations, student organizations, civil servants, teachers, and industry and business associations are all organized and controlled as functional groups within GOLKAR. Not surprisingly, these officially sanctioned organizations tend to be empty, formalistic and compliant (Mackie and MacIntyre, 1994: 21). Beyond this, the government has limited the ability of political parties to organize in rural areas (Mackie and MacIntyre, 1994: 13) and it forced the parties existing in the early days of the New Order government to regroup into two large parties (Mackie and MacIntyre, 1994: 13). More recently, the government forced Megawati Sukarnoputri, the head of the PDI, one of the major opposition political parties, out of office (Liddle, 1998: 212). The net result is that GOLKAR has dominated elected parliaments. ${ }^{16}$ To further solidify control of civil society, each agency/department of government has a unit charged with cultivating ties with private sector organizations in its area of expertise (Liddle, 1985: 73). ${ }^{17}$ As will be argued below, President Suharto's predilections for an authoritarian politics served his developmental agenda by freeing his government to focus on the design and implementation of development policies. This was particularly helpful in instances where there was little disagreement within government over development policy as in rice agriculture, education, and family planning. ${ }^{18}$

4. The New Order government learned through painful trial and error how to build mutually advantageous 'mutual hostage' relationships with big business. In these relationships the government offered favors (promotional privileges) in exchange for bribes. These mutual hostage relationships tended to be informal and particularistic and they required the creation of

\footnotetext{
${ }^{15}$ In 1993 a labor activist was killed, probably by the military, and in 1994 labor activists in North Sumatra were tortured when the government crushed an independent trade union organization (Liddle, 1998: 210).

${ }^{16}$ Candidates for GOLKAR have taken between $62.1 \%$ and $73.2 \%$ of the votes cast between 1971 and 1992 (Mackie and MacIntyre, 1994: 12).

${ }^{17}$ As Liddle (1985: 730) says, among other things, this led the government's Department of Information to cultivate ties to the Indonesian Journalists' Association.

${ }^{18}$ Warwick (1986: 460-462) argues that the success of Indonesia's family planing program can not be separated from the social, political, and economic context of the New Order government. He suggests (Warwick, 1986: 460461) that the New Order's development success and its success in achieving universal primary education increased the demand for contraception. He argues that the New Order's ability to emasculate political parties and religious leaders muted potential opposition to family planning (Warwick, 1986: 462). He also argues that administrative reforms undertaken by the New Order and the banning of political activity by civil servants when combined with the muting of political opposition made it easier for civil servants to focus their energies on development program implementation (Warwick, 1986: 461-461).
} 
a bifurcated state-one enabling political leaders to simultaneously pursue developmental and domestic political objectives.

Hard and soft control of opposition political parties and organizations in civil society in Indonesia have been counter-balanced by cozy relationships between high ranking government officials and a small number of Sino-Indonesian entrepreneurs. These relationships have their origins in the independence struggles of the 1940s when regional military commanders, who found their commands under funded, developed close relationships with cukong entrepreneurs (Liddle, 1991: 415) — Chinese businessmen who traded a share of their profits for political protection. By this mechanism, high-ranking military and political elites were able to provision their commands and enrich themselves and those in their entourage. Expansion and consolidation of these informal networks between state actors and this Sino-Indonesian business community have carried over into Suharto's New Order government. The vehicle for doing so was the offering of a whole range of promotional privileges to a small number of SinoIndonesian firms. As detailed above, this included selective allocation of tariff protection; lucrative monopoly licenses and government contracts; subsidized credit by state owned commercial banks; promotional privileges from the Board of Investment (BKPM); and bans on new entry into promoted industries. In exchange for these promotional privileges, Indonesia's big SinoIndonesian conglomerates provided Suharto and his government with some of the informal finance they needed to sustain his and their power positions (Liddle, 1991: 415).

This mutually beneficial exchange allowed the Chinese to dominate and grow the economy and Suharto and the military to gain rents and political legitimacy as supporters of economic development (Campos and Root, 1996: 132-133). Suharto appears to have been particularly adept at recognizing that his commitment to economic growth could be both a source of legitimacy for his regime and a source of informal finance (Liddle, 1991: 413-415). In this particular political economy, Suharto saw the economists (along with cukong entrepreneurs) as the producers of wealth, the patrimonialists ${ }^{19}$ in his government as the distributors of it, and the

\footnotetext{
${ }^{19}$ The patrimonialists, particularly those in the State Secretariat, used rents collected from cukong entrepreneurs and state-owned enterprises, such as Pertamina, to reward and punish those who could threaten Suharto (Liddle, 1991: 418).
} 
nationalists ${ }^{20}$ in his government as embodying his vision of a strong and industrialized Indonesia (Liddle, 1991: 419). Because of this vision, Suharto depended heavily on a bifurcated stateone where the technocrats in core macroeconomic agencies maintained a competitive exchange rate and macro stability and where patrimonialists collected and disbursed rents. While Hill (1996), Gillis (1988) and MacIntyre (1993) have viewed these relationships in extremely negative terms, Campos and Root (1996: 133) and Rock (1999: 700) have suggested that they may hold the key to understanding the success of selective interventions in Indonesia.

In what follows, I demonstrate how these elements and assumptions fit nicely into a shared growth and corruption model of the political economy of development policy in New Order Indonesia. I do so by focusing on the politics of development policy in three discrete but overlapping policy arenas - macroeconomic policy, micro policies where there was a large measure of agreement within the New Order government, and micro policies where there was substantial disagreement.

\section{Macroeconomic policies}

Because technocratic control over macro policies in Indonesia has been well documented, only the broad outlines of the politics of macro polices are provided here. As is well-known, the Suharto government inherited an economy suffering from hyperinflation, plummeting investor confidence and massive capital flight, a severe shortfall in rice supplies to feed the urban and rural populations, and a virtual collapse in profitable production. Lowering inflation, restoring investor confidence, provisioning the cities with rice, and revitalizing private production were high on Suiharto's political agenda, but given his limited education, he did not have a clear idea how to achieve these goals. All that changed in 1966 following his participation in a series of seminars organized for the Army and the government at the University of Indonesia (Bresnan, 1993: chapter 3). These seminars, particularly those on economics, exposed Suharto to a small group of economists who explained how each of these problems could be overcome. Suharto was so impressed with the economists' ideas and their basic agreement about what needed to be done that he subsequently ceded control over the macro economy to them (Elson, 2001: 149).

\footnotetext{
${ }^{20}$ The nationalists in the Suharto government were a group of high level officials that favored rapid state-led industrial development based on large and technologically sophisticated projects in automobiles, aircraft production and petrochemicals (Liddle, 1991: 416-417).
} 
The economists responded by developing and implementing a very traditional macroeconomic stabilization program. They slowed the rate of growth of the money supply and credit (Hill, 1996: 32-35). They significantly reduced the fiscal deficit and successfully introduced long run restraint into fiscal policy by getting the president to adopt a balanced budget rule (Hill, 1996: 31). They unified, devalued and pegged the exchange rate to the dollar (Hill, 1996: 74). They opened the capital account in 1970 (Hill, 1996: 31). They also set out to woo bilateral aid donors, the international financial institutions, and private international capital (Winters, 1996: 54-76).

Suharto was a strong and consistent supporter of the technocrats' macroeconomic policy reform program, particularly during the early years of the program before growth resumed and when opposition to it was strongest (Elson, 2001: 160). The ultimate success of this program taught Suharto an important lesson, one that he never forgot, macroeconomic stability was essential to the success of his development and political agendas. ${ }^{21}$ Because of this, he tended to turn to the economists when macro stability was threatened. This happened in the early 1970s when he relied on the technocrats to eliminate international borrowing by Pertimina and stave off a debt crisis (Winters, 1996; 84-90). It happened in 1980s when he relied on the technocrats to liberalize the economy following the failures of second stage import substitution and the decline in oil prices (Winters, 1996: chapter 4). And it happened in 1996 and 1997 following the onset of the financial cum currency crisis (Pincus and Ramli, 1998).

2. Microeconomic policies in rice agriculture, education and family planning.

The role of the macro technocrats in New Order Indonesia is well-known. What is less well recognized is that these same technocrats exerted large sway over micro-economic policies, particularly in areas where there was little disagreement within government either about what was important or how to proceed. This was particularly true of microeconomic policies in rice agriculture, education, and family planning.

Technocratic intervention in agricultural markets, particularly the market for rice has been significant, longstanding, and highly effective. ${ }^{22}$ It required substantial coordination with sectoral agencies, particularly the Ministry of Agriculture and Bulog, the food logistics agency. Because of this, government policy in agriculture stands out as the strongest counter example to the neo-liberal

\footnotetext{
${ }^{21}$ As one prominent government official said the technocrats used this to good advantage, They were "...very good at scaring the old man. They keep him on razor's edge... They tell him if he doesn't follow their suggestions the people will go without food and clothes or the economy won't grow." (Winter, 1996: 89).
} 
contention of a bifurcated state. As will be demonstrated below, the success of selective government interventions in rice agriculture also made it easier for the government to promote development of a significant industrial base that ultimately became export oriented. ${ }^{23}$

Because the history of government policies toward rice is also well-known only the outlines will be provided here (Timmer, 1975; 1989; 1993; and 1996). Suhatro's interest in achieving selfsufficiency in rice was the consequence of a complex set of factors. It reflected the President's rural roots and his basic fascination with agriculture. ${ }^{24}$ It reflected his earlier experience with helping farmers and villagers when he was the commander of the Diponegoro Division in Central Java in the 1950s (Elson, 2002: 60-64). ${ }^{25}$ It reflected his strong recognition that increasing rural well-being was likely to be an effective antidote to agrarian radicalism (Elson, 2001: 60). In addition, his economists helped him see the macroeconomic consequences of importing large quantities of rice and the politically stabilizing effects of low and stable rice prices for urban consumers and for the pace of industrialization. ${ }^{26}$ For all these reasons, the New Order government committed itself to achieving self-sufficiency in rice (Glassburner, 1978: 143). Rice self-sufficiency was achieved in 1984 and it has been more or less sustained.

How was this done? The simple answer is by substantial intervention in agricultural markets: in markets for agricultural inputs, agricultural credit, and agricultural output. In each instance, the government and the technocrats in macro agencies deliberately distorted market prices. The objective of intervention in output markets was to stabilize the domestic price of rice around the world price of rice (Timmer, 1993: 152). In fact, domestic rice prices were kept roughly 15\% below world prices (Gelb and Associates, 1988: 2191). What this meant in actual practice was stabilizing

\footnotetext{
${ }^{22}$ Much of what follows are drawn from Rock (2002: 488-491 and 1999: 694-695).

${ }^{23}$ This is not to say that rice price policies were used to extract a surplus out of agriculture to invest in industry, rather the net effect of polices in rice was to counter biases elsewhere in the economy that discriminated against farmers.

${ }^{24}$ In 1974, Suharto developed a ranch, Tapos, that he used as an agricultural experiment station (Elson, 2002: 210). As he said at the time, "I very much feel at home in the environment of agriculture... My great interest in the problems of agriculture comes from my experience as a child (Elson, 2002: 210).

${ }^{25}$ In the 1950s Suharto created the Fourth Territory Development Foundation to raise funds to help farmers and villagers (Elson, 2002: 60). Funds raised were used to provide loans to farmers and to provide them with agricultural tools, seeds, and fertilizers (Elson, 2002, 64). Suharto even organized inspection tours to see for himself the progress farmers and villagers were making. This practice carried over into the New Order. During implementation of BIMAS, the government's rice self-sufficiency program, Suharto undertook a series of tours to villages to see first hand how the program was working. After discussions with farmers during which they revealed their dissatisfaction with the program, Suharto discontinued the program and opted for a more incentives based approach (Elson, 2002; 172).

${ }^{26}$ Because of this, the technocrats who drew up Indonesia's first five year plan argued “...the chosen field of battle is the agricultural field" (Elson (2002: 170 and 172).
} 
rice prices around a declining real world price of rice (Rock, 2002: 491). Achieving this required substantial coordination across several macro and micro agencies including Bulog, the food logistics agency; BAPPENAS, the planning agency; the Ministry of Finance; the Ministry of Agriculture, the President's Office; and EKUIN, the Coordinating Ministry for Economics, Finance, and Industry (Timmer, 1993:151). The Ministry of Finance was the key organizer of an analytical process that resulted in the government setting floor and ceiling prices and controlling imports (Timmer, 1993: 158). This gave one of the key macro agencies substantial influence over one of the key sectoral, or micro agencies, Bulog. Although this effort has not been without its own problems, it has, on the whole been quite successful (Timmer, 1993). ${ }^{27}$

But this was not the only intervention in rice markets. Because farmers had limited experience with commercial fertilizer and with high yielding seeds, the government subsidized both and it subsidized credit to farmers so they could purchase these new inputs. ${ }^{28}$ These subsidies were used to overcome failures in information markets by significantly improving output to fertilizer price ratios (Booth, 1989: 1243). Information failures were also addressed by an aggressive and government funded agricultural extension program (Hill, 1996a: 129). Much of this was funded out of the revenue windfall that accompanied the oil price shocks of the $1970 \mathrm{~s}^{29}$

The government's highly successful selective intervention in rice agriculture undoubtedly made it easier for the government to promote, through selective interventions, an indigenously owned import-substitution industrial base behind protective barriers. Three specific aspects of the government's rice policies had positive impacts on the industrialization program. Self-sufficiency meant that scarce foreign exchange could be used for importing capital and technology for industrialization rather than to buy rice. Because of large swings in world rice prices, the thinness of world rice markets, and the large pull on prices exerted by Indonesia when it entered rice markets, large Indonesian imports of rice exerted a destabilizing influence on the macro economy. This undermined growth and investment elsewhere in the economy, including in industry (Timmer, 1989). Rice price stabilization helped overcome this problem. Finally, stabilization of domestic

\footnotetext{
${ }^{27}$ Bulog has also been associated with mismanagement and corruption and the strategy of the 1970s has bequeathed a rather rigid food pricing policy (Jones, 1995) and Timmer (1996: 51 and 69).

${ }^{28}$ Between 1968 and 1974, farmers received between $19 \%$ and $42 \%$ of all central bank credit subsidies (MacIntyre, 1995: 150).

${ }^{29}$ During the first oil price shock, agriculture received $13 \%$ of all development spending. Between $4 \%$ and 30\% of this was for fertilizer subsidies (Gelb and Associates, 1988: 208).
} 
rice prices around a declining world price of rice buoyed up profits in the industrial economy as this translated into a tendency for real wages to follow the price of the primary wage good-rice. As Timmer (1996: 62-68) has demonstrated, rice price stabilization increased macroeconomic growth by about .5\% per year between 1969-95 leaving real GDP 11\% higher than it would have been without the stabilization program. And as Rock (2002: 498-504) has recently demonstrated, rice price stabilization also contributed to a much more rapid rate of growth of the industrial sector.

But technocratic influence in micro markets did not stop with interventions in agriculture. The technocrats exercised substantial influence on both the country's highly successful family planning program and its equally successful educational opportunities expansion program. The New Order's stunning success in family planning - the total fertility rate declined by more than $50 \%$ from 5.57 in 1966 to 2.75 in 1996 - is particularly remarkable given what preceded it and the presumed obstacles facing it. To begin with, President Sukarno was unalterably opposed to family planning and he declared that Indonesia would have no trouble supporting a population two or three times what it was in 1961 (Hull, 1994: 126-127). He also feared that a family planning program might antagonize the country's large Muslim population (Hull, 1994: 127). To make matters worse, many believed that opposition from the Muslim population or the country's conservative religious leaders, a presumed cultural predilection for large families, and a disorganized government severely limited any chance of success in family planning (Hull, 1994: 134).

While Suharto was initially somewhat hesitant to support family planning, fearing that it might antagonize Muslim religious leaders, his technocrats were able to impress upon him the connections between unbridled population growth, agricultural development, employment growth and general prosperity (Elson, 2002: 173). Subsequently, he became a vital spokesperson for Indonesia's family planning program. He signed the UN Declaration on Population in 1967 (Elson, 2002: 173). In 1968, he established a national family planning institute, which he elevated to the National Family Planning Coordinating Board in 1970 (Hull, 1994: 128). The chair of this board reported directly to Suharto (Hull, 1994: 128). In addition, the president routinely signed family planning decrees, gave verbal assurances to doubters among the necessity of the program, and attended ceremonies for couple who had become family planning acceptors (Warwick, 1986: 455). He also frequently made strong pro-family planning statements to the press; posed for photographs with the Chair of the NFPCB; and supported the program with critical budget support particularly 
during hard times when the overall government budget was being reduced (Warwick, 1986: 455). In the end, Suharto considered the success in family planning, along with rice self-sufficiency, among the most notable achievements of the New Order. ${ }^{30}$ As Bresnan (1993: 281-282) says, Suhato was sympathetic and supportive of family planning because he saw it in the interests of a group - Javanese rice farmers - with which he had a basic affinity.

But technocratic influence over family planning was not limited to the technocrats garnering of Suharto's support for family planning, in the early 1980s the government appointed a respected technocrat to lead the government's newly created State Ministry of Population and the Environment (Hull, 1994: 130). This forced the NFCPB to adopt a lower profile on population issues (Hull, 1994: 128) and it placed at least one technocrat in a position of formal oversight of the program. Although not much is known about the ultimate influence of the technocrats on the design and implementation of the family planning program, the program that developed was quite unique and results oriented. To begin with, it aimed to cut the crude birth rate by $50 \%$ over twenty years (Warwick, 1986: 456). Attempts to meet this goal were driven by the setting of quantitative targets for contraceptive prevalence rates by locale and date. ${ }^{31}$ Provincial targets were negotiated between the NFCPB and provincial governors. Lower level targets were negotiated between lower level political units and the one directly above it. Performance relative to target, at each level within the system, was monitored by real time data. ${ }^{32}$ When performance fell short of a target, the political unit at the next highest level had the authority to press for better results (Warwick, 1986: 458). The distribution of contraceptives was also tied to real time data. ${ }^{33}$

\footnotetext{
${ }^{30}$ In the beginning of his biography, Suharto lauds his regime's success in development, rice agriculture, and family planning (Elson, 2001: 235). As he says of the latter, "Today, around six in ten couples of childbearing age consciously follow our family planning program..." (Elson, 2001: 235).

${ }^{31}$ The NFPCB's local offices worked closely with the central office in Jakarta to set targets and devise implementation plans for each year (Warwick, 1986: 457). The central office of the NFPCB used assumptions about contraceptive prevalence with data collected from a province to set subsequent contraceptive prevalence targets. The NFBCP also taught local governments how to set their own targets (Hull, 1994: 133).

${ }^{32}$ The NFPCB has a special arrangement with the postal service for obtaining and returning real time data on a region's performance. Each locale collects the data and sends it to the postal service. The postal service ships one copy to the NFPCB in Jakarta and another to the administrative unit one level up from the local. The NFPCB collates and analyzes data and returns results within 30 days from their new estimate of contraceptive prevalence (Warwick, 1986: 459).

${ }^{33}$ Each clinic, sub-district, city, regency, and province was linked to a warehouse that provided contraceptives and when reported inventories fell below targeted levels, warehouses sent additional supplies without being asked (Warwick, 1986: 460).
} 
Those who implemented Indonesia's family planning program were also particularly nimble in overcoming opposition to the program from local religious leaders, community leaders, and young couples. Initially, local conservative religious leaders were quite hostile to the program because they thought it promoted sterilization and abortion; because it used males to examine patients; and because it opened a taboo topic to public discourse (Warwick, 1986: 467). Officials in the NFPCB worked hard to overcome each of these objections. They omitted sterilization and abortion from Indonesia's family planning program. They promoted the use of female examiners. They relied on the Department of Religious Affairs to demonstrate that contraceptive practices were not inconsistent with religious teachings. They also co-opted some religious leaders by providing them with all expense paid formal training programs in family planning. In the end, many local religious leaders became active supporters of the program. ${ }^{34}$

Because a 1981 survey revealed that couples were frequently unwilling to use contraceptives if they thought family planning was seen as a shameful practice in their village (Warwick, 1986: 466), local NFPCB officials worked closely with traditional community leaders to build a climate within villages supportive of family planning practice. In fact, institutionalizing support for family planning practices was another key objective of the program (Warwick, 1986: 455). The key institutional tool for doing so was a village level family planning acceptor group composed of couples who used contraceptives. Acceptor groups met informally, distributed contraceptives, kept records, and recruited new clients (Warwick, 1986: 458). The government encouraged village headmen and their wives to take a leadership role in these groups (Warwick, 1986: 458). It appears that most did. Many played an active role in setting contraceptive prevalence targets and village headmen were routinely held accountable for meeting these targets (Warwick, 1986: 465).

In addition, the officials of the NFPCB built on other government programs and agencies when and if they thought doing so helped change the social climate toward family planning and/or if they thought it would contribute to a rise in contraceptive prevalence. The NFPCB routinely used medical professionals to deal with side effects or fears of side affects (Warwick, 1986: 472). When the Ministry of Health began training traditional birth attendants in more sanitary birth procedures, the NFPCB piggybacked on this program by training birth attendants in contraceptive practices

\footnotetext{
${ }^{34}$ Warwick (1986: 467) states, "The shift among religious leaders from a stance of hostility to one of active support,
} 
(Warwick, 1986: 468). As a result, many of them became active supporters of the program (Warwick, 1986: 458). Subsequently, the NFPCB linked the family planning program to village health centers and village level nutrition programs (Warwick, 1986: 469). Program officials also learned how to use local organizations, such as the banjar or local hamlet associations in Bali. ${ }^{35}$ Despite a number of significant problems, it would be hard to consider this program anything other than a remarkable success. ${ }^{36}$

While the technocrats led in development of macroeconomic policies, and policies in rice agriculture and family planning, they were pushed, by their critics ${ }^{37}$, into a massive and successful expansion of the country's primary education system. As a result, the technocrats were forced to shift their emphasis from macroeconomic stability and growth to broad-based development (Chalmers and Hadiz, 1997: 56). This was particularly manifested in the government's large-scale school construction program for primary education (Instructsi Presiden-Sekolah Dasar) launched in 1973 (Warwick, 1986: 462). As Chalmers and Hadiz (1997: 59) say, the program was the direct result of strong political pressure on government (and the technocrats) from students and intellectuals.

Once the rise in oil prices ${ }^{38}$ made it possible to rapidly expand access to primary education, the government responded in very quick order. Between 1973 and 1978 the government spent more than $\$ 500$ million, or roughly $1.5 \%$ of 1973 GDP, to construct more than 61,000 new primary schools doubling the number of schools (Duflo, 2001: 795). This reputedly made Indonesia's primary school expansion program the largest primary school construction program ever undertaken in the developing world and it led to the creation of about 1 school for every 500 primary school age

seen in many parts of Indonesia, was a field triumph for the program."

${ }^{35}$ By the mid-1980s, banjars were monitoring the family practice of each household unit by requiring husbands to report on the family practices in their household (Warwick, 1986: 471)

${ }^{36}$ Occasionally, the program relied on heavy-handed practices as when the military in East Java rounded up village women and forced them to go through a house where IUDs were being inserted, but these kinds of practices did not last (Warwick, 1986: 470). The program also suffered from bureaucratic infighting, particularly between the NFPCB and the Department of Health and the NFPCB and the Central Bureau of Statistics (Hull, 1994: 130).

${ }^{37}$ Chalmers and Hadiz (1997: 56) argue that the focus of the technocrats on macroeconomic stability, economic growth and foreign investment began drawing heavy criticism as early as 1967-68. Some criticized the contractionary nature of monetary and fiscal policy. Others criticized over reliance on foreign, particularly Japanese, capital. Still others emphasized the degree to which the program ignored equity considerations within Indonesia. All of these criticisms led the technocrats to focus more on development and less on growth (Chalmers and Hadiz, 1997: 56).

${ }^{38}$ As a result of the increase in oil prices in the 1970s, real development expenditures more than doubled between 1973 and 1980 (Duflo, 2001: 795). 
child (Duflo, 1997: 795). The government also used a World Bank loan to undertake a parallel program to train new teachers. This resulted in a $43 \%$ increase in the number of primary school teachers without a notable reduction in the number of teachers meeting minimum qualifications (Duflo, 2001: 795).

As in the country's family planning program, school construction was driven by a quantitative objective - achieving universal primary education for girls and boys across all of Indonesia's 13,000 islands. Because of this, the number of schools constructed in a district was set in Jakarta. The central government used an allocation formula for school construction that put new primary schools in a district in proportion to the number of children of primary school age in a district not enrolled in 1972 (Duflo, 2001: 797). This meant that by the end of the program there was one school for every 500 students in Indonesia. Since the central government's Department of Education and Culture (DOEC) was responsible for the school curriculum, textbooks, the delivery of textbooks to warehouses in districts, teacher training, and the placement of teachers in schools, DOEC was more or less able to match teachers and textbooks to the new schools. ${ }^{39}$ While this whole process has not been totally $\operatorname{smooth}^{40}$, the results-achievement and maintenance of universal primary education for boys and girls since 1983 - have been nothing short of remarkable. At least one study (Duflo, 2001: 812) attributes this program with significantly increasing the education levels and the real wages of those school age children who benefited from being in a district where one or more schools were built. Another study (Jones, 1994) indicates that Indonesia's investments in education are largely consistent with the rate of return literature on education, this suggests that the technocrats may well have played an important role in this program too. There is also parallel evidence that primary education of women contributed to a decline in child mortality across Indonesia (Mellington and Cameron, 1999).

3. Microeconomic (industrial, trade, market access, credit, and investment promotion) policies in which there was not agreement within the New Order government

\footnotetext{
${ }^{39}$ The DOEC has a dense network of offices that extend from Jakarta to each province, district/municipality, and sub-district in Indonesia (King, 1995/96: 80).

${ }^{40}$ King (1995/96: 81-84) maintains that multiple and overlapping bureaucratic structures and bureaucratic infighting have contributed to sup-optimal performance. Jones and Hagul (2001: 207 and 210) argue that despite achieving and maintaining universal primary school enrollment, the system suffers from severe quality problems and wide regional disparities in graduation rates. A recent World Bank report (1998: 23-45) argues that primary education in Indonesia suffers from poorly trained teachers, too little time spent in school in grades 1 and 2, low quality textbooks, and insufficient resources.
} 
The industrial promotion policies of the New Order-its industry specific, trade, market access, credit, and investment promotion policies - are the least understood development policies of the New Order. Some (World Bank, 1993; MacIntyre, 1994 and 1996; Winter, 1996 and Hill, 1996) contend these policies simply served patrimonial rent-seeking functions. The analysis of others (Chalmers and Hadiz, 1997 and Pangaribuan, 1995) suggests that disagreements within the New Order government over industrial policies led to such frequent changes in policies that they probably lacked enough coherence to be effective. Still others (Robison, 1986 and Rock, 1999) contend that these policies are more coherent than most to admit. What I hope to demonstrate is that throughout the history of the New Order its actual industrial policies ${ }^{41}$ reflected substantial agreement over ends, substantial disagreement over means to achieve those ends, and remarkable continuity in policies despite disagreement over means.

There is little doubt that Indonesia's colonial experience fostered a long lasting and deepseated mistrust of markets, foreign investment, and the West (Gillis, 1984; Timmer, 1975; and Hill, 1996a). Individuals in the early and nascent nationalist movement often defined the independence struggle as a struggle against an economic imperialism that left Indonesia with a distorted economy - an ekonomie kolonial - a colonial economy characterized by a modern sector controlled by foreigners and a poor, stagnant rural sector dominated by Indonesians (Chalmers and Hadiz, 1997: 6). By the early 1940s, most politicians agreed that this outcome was a direct consequence of capitalism and economic liberalism (free markets) (Chalmers and Hadiz, 1997: 7). Between 1945 and 1949 nationalist politicians articulated a vision of an alternative economy-an ekonomie nasional - a national economy that would be strong, integrated, diversified, industrialized, indigenously owned, and much less dependent on the export of primary products (Chalmers and Hadiz, 1997: 8). Because of the inherent weaknesses of Indonesia's indigenous capitalist class, most politicians and government officials presumed that the government would have to play a large role in fostering the development of an indigenous bourgeoisie. ${ }^{42}$

Following independence the government's initial efforts to promote indigenous industrial capitalists relied on allocating import substitution promotional privileges to pribumi entrepreneurs

\footnotetext{
${ }^{41}$ By industrial policies I mean all those policies - including selective promotion of particularly industries, trade policies, market access policies, credit policies and investment promotion policies - designed to affect industrial development.

${ }^{42}$ Suharto appears to have thought in terms of stages of development that would take more than a decade to achieve and ultimately ending in a substantially industrialized economy (Elson, 2001: 168).
} 
(Chalmers and Hadiz, 1997: 10). When that failed, the government turned to investment in several large industrial enterprises in the hopes of stimulating backward and forward linkages to small-scale enterprises (Chalmers and Hadiz, 1997: 11). When that too failed, the Sukarno government turned to expropriating foreign capital and investing in large-scale state-owned enterprises (Chalmers and Hadiz, 1997: 12). As we know, that effort also failed. These failures provided an opportunity for the technocrats in the new Suharto government to devise and implement a somewhat more liberal approach to international capital and foreign investment. ${ }^{43}$ But given elite and popular fears of foreign capital, this policy ultimately provoked substantial criticism culminating in the Malarai (anti-Japanese) riots of 1974 . $^{44}$ This backlash and the failures of the previous government appear to have provided a breathing space for several alternative strategies for creating Indonesia's ekonomie nasional.

Subsequently, four overlapping but somewhat distinct individuals/agencies within the New Order government began contesting for control of industrial policy. ${ }^{45}$ The technocrats continued to favor policies that promoted growth and economic efficiency. While they did not (and could not) openly oppose a more interventionist approach to industrial development, they were deeply concerned about the efficiency and growth implications of interventionist policies. ${ }^{46}$ A group of economic nationalists in Pertamina, ASPRI, and the Center for Strategic and International Studies proposed using access to state privileges to create a small number of large indigenous, albeit SinoIndonesian, industrial groups, that could ultimately compete and contend with foreign multinationals (Pangaribuan, 1995: 9). Some in this group ${ }^{47}$ favored fostering outward-oriented industrial groups that could also help Indonesia to take advantage of the international market (Chalmers and Hadiz, 1997: 71). A third group of economic nationalists in Sekneg, the State Secretariat, favored using promotional privileges to create indigenously owned (pribumi) import substitution industries (Pangaribuan, 1995: 10). A fourth group of technologists or engineers

\footnotetext{
${ }^{43}$ The Foreign Investment Law of 1966, which liberalized requirements on foreign investment, was the culmination of a sustained process to attract foreign capital (Winters, 1996: 54-76).

${ }^{44}$ These riots and the political machinations surrounding them led the government to severely restrict the role of foreign capital in Indonesia.

${ }^{45}$ Pangaribuan (1995) offers the single best description of the battles among these individuals/groups for control of industrial policy.

${ }^{46}$ Because of this concern, the technocrats opposed both those who wanted to use promotional privileges to support the cukong entrepreneurs (Pangaribuan, 1995: 35) and those who wanted to use those privileges to support pribumi entrepreneurs (Pangaribuan, 1995: 55).
} 
centered in BPPT, the country's premier public science and technology institute, and on B. J. Habibie favored the use of state-owned enterprises in high tech industries - aerospace, steel, petrochemicals - to spearhead a technological leap forward industrial development strategy (Chalmers and Hadiz, 1997: 176-181). Throughout the New Order, these groups competed for control over industrial policies by forming, breaking, and reforming alliances to solve particular problems $^{48}$, block particularly policies that alliance members opposed ${ }^{49}$, or to promote their own policy agendas. ${ }^{50}$ Suharto appears to have skillfully managed this competition among his advisors by demotion $^{51}$, promotion $^{52}$, and rehabilitation of previously demoted advisors ${ }^{53}$. He also appears to have feared giving any one group too much power (Pangaribuan, 1995: 57, 64 and 67).

Much of the discussion (Schwarz, 1999; Winters, 1996 and Pangaribuan, 1995) of these intra-bureaucratic struggles focuses on the tension between the technocrats and the so-called patrimonialists over whether industrial policies were to be used for developmental as opposed to patrimonial purposes. In my view, this amounts to a serious misreading of the intra-bureaucratic struggles, the commitment of each group in these struggles to a developmental agenda, as well as to a serious misreading of how corruption worked in New Order Indonesia. To begin with, at least some of the struggles must have reflected honest disagreements over how to create an ekonomie nasional. The New Order was simply too developmentally oriented for this not to have been the case. There is other evidence to support such an interpretation. For his part, Suharto was not opposed to reigning in proponents of any one view when they failed to perform developmentally. This happened when Suharto allowed the technocrats to move in on both Habbie and Sutowo, the

\footnotetext{
${ }^{47}$ The most prominent supporter of using the state to create large, integrated, and outward oriented conglomerates to contend with the multinationals was Jusef Panglaykim (Chalmers and Hadiz, 1997: 78-82)

${ }^{48}$ The technocrats and officials in Sekneg successfully joined forces in the early 1970s to reign in Pertamina's foreign borrowing (Pangaribuan, 1995: 38-39).

${ }^{49}$ In the early 1970s, the technocrats joined with the pribumi nationalists in Sekneg, the State Secretariat, to undermine the influence of those in ASPRI who favored the cukong entrepreneurs (Pangaribuan, 1995; 35-37). Individuals in ASPRI responded by cultivating relationships with individuals in one of the more powerful sections of Sekneg, the Office for the Supervision and Operations of Development or Setdalopang (Pangaribuan, 1995: 3637).

${ }^{50}$ Relationships between the technocrats and officials in Sekneg ultimately broke down over the use by Sekneg of centralized control over government contracts to promote pribumi entrepreneurs (Pangaribuan, 1995; 53).

${ }^{51}$ Following the Malari affair, ASPRI was disbanded and Ali Moertopo lost influence (Pangaribuan, 1995: 37-38).

${ }^{52}$ In 1980 Tim Keppres 10 significantly increased the power of the State Secretariat by giving it substantial control over government contracting (Pangaribuan, 1995: 53-54). Winters (1996: 123-142) sees this development as a clear shift within the New Order favoring the patrimonialists. Pangaribuan (1995: 52-54) sees it more as an attempt to reign in excessive government spending and reduce corruption.
} 
head of Pertamina. But it also happened when the technocrats' more or less open door policies toward foreign capital created a backlash of criticism. By these kinds of actions Suharto communicated to individuals in each faction that his support for them and their policies depended on results. ${ }^{54}$ Sometimes, this even led those in one faction who opposed the policies of those in another, to agree that their opponents were right. ${ }^{55}$

It is also important to note that those in Sekneg, who favored promotional privileges for pribumi entrepreneurs, were just the latest in a very long line of politicians who defined independence in terms creating successful pribumi entrepreneurs. This tradition is so strong among political elites in Indonesia that it is inconceivable it did not have at least some impact on official thinking. ${ }^{56}$ But the failures of the earlier efforts by government to foster successful pribumi entrepreneurs undoubtedly created political space for those who espoused alternative pathways to an ekonomie nasional. Habbie and the technologists chose a more statist approach partly because of their sympathy for a Japanese style state-led model of industrial development, and probably because of their fears that building industry around Sino-Indonesian entrepreneurs was just too politically explosive. At the same time, the regime's courting of Chinese capital in the late 1960s (Winters, 1996: 76-78), the success of the Chinese in business, and the longstanding relationships between cukong entrepreneurs and the business generals suggested that they too could be used to create an ekonomie nasional. Thus it is not particularly surprising that a group championed using them for developmental purposes.

I believe the evidence ultimately suggests that Suharto decisively committed himself over the long term to side with those in ASPRI and CSIS who favored supporting a small number of Sino-Indonesian entrepreneurs. I suspect he did so for five particular reasons. To begin with, he was never interested in sustaining ${ }^{57}$ nor was it ever politically possible for his government to sustain

\footnotetext{
${ }^{53}$ This happened with announcement of the Third Development Cabinet (1978-83) when Ali Moertopo was named Minister of Information while several of his close associates were added to the cabinet (Pangaribuan, 1995: 40)

${ }^{54}$ As Pangaribuan (1995: 43) says, by the late 1970s a clear pattern emerged between Suharto and his advisors. They would be kept as long as they served his purposes.

${ }^{55}$ This happened in the mid-1980s when Ginandjar, a pribumi nationalist in the Sekneg faction who favored import substitution polices as head of BKPM, the investment promotion agency, recognized that import substitution was no longer viable and that Indonesia would have to begin promoting export oriented industries (Pangaribuan, 1995: 65).

${ }^{56}$ Pabottingi (1995: 224-251) argues that development based on the growth of successful pribumi capitalists provides a substantial moral basis for government in Indonesia. He (1995: 233) argues that this is crystallized in the nationalist ideology, Pancasila, that stands as a testimony against colonial dehumanization

${ }^{57}$ As Pangaribuan (1995: 248) says, Suharto remained a stubborn economic nationalist who distrusted the interest of the West in the development of the Third World.
} 
the technocrats' more or less open door policy to foreign investment. I suspect that he never really believed that Habbie's state-owned enterprise approach would work either. ${ }^{58} \mathrm{He}$ was simply too committed to development and he had some evidence that a state-owned enterprise strategy might not work. ${ }^{59}$ He had very little, perhaps no evidence to lead him to believe that Indonesia's pribumi entrepreneurs could help him build an ekonomie nasional. On the other hand, the Chinese appeared to offer the best chance Indonesia had for creating an ekonomie nasional, albeit one dominated by them. At least some of their capital came from elsewhere in Asia. This suggested they had some experience in business in the international economy. ${ }^{60}$

More importantly, his regime's relationship with a relatively small number of cukong entrepreneurs solved an important political problem. It provided him with much of the informal finance he needed to consolidate his political position. He skillfully used access to informal finance to control opposition political parties (Pangaribuan, 1995: 33), expand his base of support in the bureaucracy and GOLKAR (Pangaribuan, 1995: 59-91), and to cultivate support with Indonesia's population, particularly farmers and villager. ${ }^{61}$ This combination-his need for informal finance, the cukong entrepreneurs ability to deliver economic growth, and these same entrepreneurs' weak political position — created a unique opportunity for Suharto to support progrowth policies while gaining access to the informal finance he needed to meet his political objectives. In this particular patron-client network, one Khan (1996: 691) labels patrimonial, the Indonesian government was undisputedly the senior partner with an uncontested ability to both grant promotional privileges (rents or rights) to cukong entrepreneurs and to protect the economic rights so granted. Because the cukong entrepreneurs were a scorned ethnic minority

\footnotetext{
${ }^{58}$ Even though he was quite enamored with Habibie's vision and accomplishments (Elson, 2001: 264-265).

${ }^{59}$ In addition to problems with Pertamina, P.T. Krakatau, the state-owned steel firm, experienced such serious financial problems that Suharto asked the technocrats to intervene (Pangaribuan, 1995: 36).

${ }^{60}$ But open-ended support for them was not possible either. This would have subjected Suharto, even more than it did, to a deep-seated criticism from Indonesia's pribumi entrepreneurs that the New Order had pushed them aside forcing them to face Furnivall's old 'loaded dice' in their competition with foreign capital and the Chinese (Pabottingi, 1995: 229). Because of this, he was apparently willing to use the technocrats to reign in at least some of their excessive rent-seeking activities. And he used government support for both the technologists and pribumi entrepreneurs to remind the cukong entrepreneurs that he had alternatives to fall back on if they failed him.

${ }^{61}$ Setadalopbang managed a host of development projects for Suharto, including construction of orphanages, bridges, mosques, hospitals, it also provided support for transmigration and health care (Pangaribuan, 1995: 32). Funding for these projects came from a variety of private sources and most appear to have been channeled through the president's Presidential Aid or BANPRES (Pangaribuan, 1995: 32). These projects have their origins in the 1950s when Suharto was a commander in the army in the 1950s (Elson, 2001: 60-64). During the Fourth Five Year Plan, more than 2,200 such projects costing Rp 187 million were financed this way (Pangaribuan, 1995: 32).
} 
totally lacking in political power, they had few opportunities to either challenge the government's economic priorities or to turn this exchange of promotional privileges for bribes into simple growth retarding rent-seeking behavior. They also had to suspect that their continued access to privileges depended on them investing wisely to grow the economy. ${ }^{62}$ This was not the case for Indonesia's pribumi entrepreneurs. They were not a particularly good source of informal finance (Pangaribuan, 1995: 60 and footnote 30 on pages 70-71). They had both more political power ${ }^{63}$ and a 'birth right' to protection (Chalmers and Hadiz, 1997: 6-8). This made it much harder for the New Order government to keep its patron client ties with pribumi entrepreneurs from degenerating into clientistic-based growth-retarding rent-seeking.

This patrimonial patron-client relationship between a small number of government officials and a similarly small number of cukong entrepreneurs could well have degenerated into simple plunder as Zaire, or rent-scraping as in the Philippines ${ }^{64}$, but both parties learned that they could mutually gain if they learned how to cooperate. ${ }^{65}$ This opportunity for mutual gain

\footnotetext{
${ }^{62}$ There were two reasons for this. First, growth and profits were needed to provide the Suharto government with the informal finance it needed to meet its political objectives. Failure to do so might well reduce the government's willingness to provide privileges. Second, the cukong entrepreneurs, no doubt, gained some protection by their ability to deliver economic growth. This had to enable Suharto and his supporters to deflect at least some of the criticism directed at his regime's support for Chinese business. What this means is that the government was able to, at least informally, monitor whether rents were used to enhance growth.

${ }^{63}$ Their power base within the regime rested in Sekneg, a bastion of support for pribumi entrepreneurs, and Golkar, particularly in the 1980s (Pangaribuan, 1995; 59-60).

${ }^{64}$ For discussion of plunder of the private sector by government in Zaire and rent-scrapping in the Philippines see Wedeman (1997).

${ }^{65}$ Wedeman (1997) demonstrates how this kind of relationship generated growth-oriented policies that allowed government officials in Korea to collect dividends from the highly profitable firms they protected. Kang (2002) provides an even more interesting explanation for how this combination was able to generate high-speed industrial growth in South Korea. His central thesis is that if a balance of power exists between a small number of political and business elites, money politics and corruption - the exchange of favors (promotional privileges) for bribes - can reduce transactions costs and make long term investment by business productive (Kang, 2002: 4). He demonstrates how this outcome is achieved by focusing not, to paraphrase him (Kang, 2002: 7), on individual policy choices of the developmental state, such as the shift to export-led industrial development, but rather on the larger institutional environment governing business-government interactions. As he says, business-government relationships fall, more or less, into one of four categories. States can be either coherent or fractured while business can be either concentrated in a small number of diversified business groups or weak and dispersed in a large number of small firms (Kang, 2002: 15). When states are coherent and business weak and dispersed, top down predatory behavior by government of business becomes possible. If this happens, public sector corruption and rent-seeking can be too large relative to the economy, private sector capital accumulation slows, and growth breaks down. If states are fractured and business is concentrated, bottom-up private sector rent-seeking by business can occur as business learns that it can overwhelm the state (Kang, 2002: 16). This too can lead to substantial rent-seeking and corruption relative to the size of the economy and it too can slow capital accumulation and growth as business shifts investment out of productive activities and into rent-seeking activities.

But if government and business are equally strong and coherent, a prisoner's dilemma can emerge where business and government act as mutual hostages. Under this circumstance, each is powerful enough to harm the
} 
reinforced Suharto's basic commitment to development as the adoption of pro-growth development policies enabled him to collect more dividends. Because of this, the industrial policies of the New Order were by and large growth enhancing. They encouraged government officials and the cukong entrepreneurs to reinvest their profits in Indonesia. This limited capital flight and probably explains why the investment to income ratio in Indonesia was so high for so long. ${ }^{66}$ But the government also signaled to the cukong entrepreneurs, through adoption of an open capital account policy that they could move their capital abroad if the regime's policies threatened their economic rights. This, no doubt, acted as a brake on the government taking too much from their big business partners, turning against the cukong entrepreneurs, or allowing the technocrats to challenge the structure of economic rights the regime provided them. For most of the New Order, the cukong entrepreneurs used promotional privileges (government favors) to expand their operations, grow the economy, and provide Suharto with much of the informal finance he needed. In this model, money politics, corruption and economic growth were mutually reinforcing as politicians learned not to squeeze the golden goose (business) too hard and business learned to use its rents to grow the economy. This pattern of cooperation between government and business in Indonesia appears to have pushed at least some of the corruption and rent-seeking ${ }^{67}$ in a developmental direction by reducing transaction costs making long-term investments by business profitable and productive.

Substantial evidence exists to support this interpretation of the New Order's industrial policies. To begin with, promotional privileges - tariff protection, preferential access to lucrative

other, but each may be deterred from doing so because of the damage each can impose on the other (Kang, 2002: 17). While a war of attrition and no growth are possible, government and business can also ultimately learn to grudgingly co-operate (Kang, 2002: 18). Kang believes there are strong incentives to do so, as all this requires is a simple exchange of favors (promotional privileges) for bribes. In his model of cooperation, politicians in Korea, starting with President Park, used bribes to buy votes, build a patronage machine that rewarded supporters and sustained their power position, while meeting their desires for greed. For its part, business used favors, particularly cheap capital, to expand their operations and grow the economy. In this model, money politics, corruption and economic growth were mutually reinforcing (Kang, 2002: 97) as politicians learned not to squeeze the golden goose (business) too hard and business learned to use its rents to grow the economy. This pattern of cooperation between government and business appears to have pushed corruption and rent-seeking in a developmental direction by reducing transaction costs making long-term investments by business profitable and productive.

${ }^{66}$ The investment to GDP ratio averaged 25.6\% between 1970 and 1997 (World Bank, 2000).

${ }^{67}$ This appears to have been less true of rents granted to pribumi entrepreneurs and the rents extracted from stateowned enterprises like Pertamina, Perhutani, and Bulog. It probably also does not apply to rents extracted by the president's children. What this means is that the analysis of rent allocation and rent-seeking in New Order Indonesia 
monopoly licenses and government contracts, preferential access to subsidized credit, to BKPM promotional privileges and government bans on new entry in promoted industries - overwhelmingly favored the cukong entrepreneurs (Robison, 1986: 41-47 and 133-144). Despite recurrent shifts in industrial policies sometimes favoring pribumi entrepreneurs, sometimes favoring Habbie's high tech industries, and sometimes favoring the technocrats' more liberal trade and investment policies, many of the privileges showered on cukong entrepreneurs were never either scaled back or removed. One consequence of the Suhatro government's long term support for the cukong entrepreneurs is the domination of Indonesian industry by large firms combined into a small number of family-centered conglomerates. By the mid-1980s, 55\% of all non-oil manufacturing firms were in industries where four firms accounted for 40\% or more of all sales of an industry (Hill: 1996a: 167). By 1996, the four leading firms in more than one-half of all of Indonesia's industrial branches produced more than $75 \%$ of total output in those branches (Dehanini, 2000: 122). Because Indonesian firms are conglomerated across industries, this understates the degree of seller concentration. Some of these "firms" such as the Salim Group are enormous. In 1992 its sales totaled 20,000 billion rupiah accounting for nearly $20 \%$ of sales of the largest hundred business groups in Indonesia (Sato, 1993: 409).

There is also evidence that favored cukong entrepreneurs learned how to successfully respond to changes in incentives provided by government. The experiences of two of Indonesia's most influential entrepreneurs and so-called "crony capitalists" appear to be typical (Sato, 1993 and 1996). Liem Sioe Liong, founder of the Salim Group, and William Soeryadjaya, founder of the Astra Group, began as merchants and traders. ${ }^{68}$ In both instances, group growth strategies were largely dependent on government policies. When the government began promoting first stage import substitution industrialization (ISI) the Salim group got into cotton spinning and weaving and flour milling. During second stage import substitution it diversified into cement and steel (Sato, 1993: 414, 417-421). For its part, Astra assembled automobiles during first stage import substitution industrialization, while during second stage ISI it moved into component parts manufacture (Sato, 1996: 254-257). As Sato (1996: 257) states Astra's shift from distribution, to assembly, to components parts manufacture

needs to distinguish among the various mechanisms used for rent-allocation and rent-seeking. Some are likely to have been much more developmental than others.

${ }^{68}$ Although, it needs to be said, Astra was not particularly close to Suharto (Elson, 2001: x). 
"... reflects the Astra Group's strict adherence to the

government's localization policies..." (1996: 257).

As government policy shifted in the 1980s to promote exports, both groups responded. Astra began exporting batteries and spark plugs, Toyota engines, and Komatsu forklift frames (Sato, 1996: 260). It depended on its joint partnerships with Japanese multinationals to do this. And it expanded entry into manufactured exports by developing relationships with different multinationals (Sato, 1996: 261). It also invested in agro-exports (Sato: 1993: 296). The Salim Group's response to the new export incentive system was equally impressive. Salim reduced investments in cement, liquidated investments in steel, and moved into export manufacture (sport shoes, toys, garments, and leather goods) and export oriented agri-business (pig and shrimp farming, fish and poultry farming, orchards, fresh fruit and vegetable cultivation, and oil palm and sugarcane plantations (Sato, 1993: 423)). Salim also invested overseas in chemicals production and in the distribution and sale of consumer goods. By 1991, one of its overseas ventures was selling 55\% of its output in Europe and the U.S. (Sato, 1993: 426).

There is also some evidence that the New Order's industrial policies contributed to technological learning, productivity growth, and the creation of a strong, integrated, diversified, industrialized, and outward oriented ekonomi nasional. Over the period when industrial policy was dominant (1971-1981), the manufacturing sector's share in GDP grew two times faster than the norm while there was little change in overall economic growth. ${ }^{69}$ Because of this, manufacturing more than doubled its contribution to overall economic growth while agriculture's contribution to growth declined by nearly half (Hall, 1996a: 21). While this was happening, labor productivity in Indonesian manufacturing was increasing relative to labor productivity in manufacturing in the U.S. (Szirmai, 1994: 73). Although overall total factor productivity (TFP) growth in manufacturing was low, annual TFP growth of three highly promoted sectors (non-metallic minerals, basic metals, and wood products) was quite high $(10.3 \%, 19 \%$, and $4.2 \%)$ as a "virtual technological revolution occurred" in (several of) these industries (Aswicahyono, Bird, and Hill, 1996: 357-358). This suggests that substantial learning and technological upgrading was occurring in at least some of the promoted industries. In addition, if industrial policies were successful, the economy should be more industrialized, diversified, and outward oriented than predicted by international norms. As I have

\footnotetext{
${ }^{69}$ The economy grew at $8.2 \%$ per year between 1972 and 1981 compared to $8.5 \%$ per year between 1967 and 1972
} 
argued elsewhere (Rock, 1999), the share of manufactures in GDP and the share of manufactures in total exports are larger than expected while the export concentration index is much lower than expected.

\section{Summing Up}

In 1965 Indonesia was one of the poorest countries in the developing world (Meier, 1970:

23). At the time, well-informed observers gave it little chance of overcoming poverty and underdevelopment (Higgins, 1968; Geertz, 1963; Myrdal, 1969). Yet prior to the recent collapse of the currency and economy, Indonesia was widely heralded as one of East Asia's high performing economies (Hill, 1996a; World Bank, 1993; and Campos and Root, 1996). Because of longstanding and extensive, even by developing country standards, dirigiste microeconomic policies - particularly in agricultural markets, in credit markets, and in trade and industry policies - and equally longstanding corruption and rent-seeking, explaining this success has not been easy. Neo-liberals have done so by dismissing microeconomic interventions as irrelevant to the economy's good performance while warning that continued dirigisme and corruption could bring an end to the shared growth miracle (Hill, 1996b and World Bank, 1989). The financial cum currency crisis of $1997 / 98$ has been taken as evidence that this has finally happened.

I have taken issue with this interpretation of development policy in Indonesia by arguing that the New Order government assembled a pro-growth political coalition that enabled it to use selective policies in a wide range of areas to meet its development objectives while simultaneously meeting its political objectives. I also provided an interpretation of development policy and development policy change that integrates at least some of the corruption into the New Order's growth story. But this system could have run amok if the Suharto government lacked substantial commitment to development, was too beholden to popular groups in civil society, if it took too much, if business failed to respond to incentives, or if no corrective mechanism existed to weed out bad investments. Fortunately, most of the time, these things did not happen. As I argued, political elites in Indonesia were deeply committed to increasing national power and national strength in a hostile world and in pursuing economic development, both as a component of national power and as a goal in its own right. They were also committed to a private enterprise approach to development. Commitment to development and private 
enterprise meant that the government could not take too much. The government in Indonesia also worked hard, continually and quite successfully, to limit popular group pressures on the state. This freed it from populist redistributive demands that have been so corrosive of growth elsewhere and enabled the government to focus on development, by among other things, developing informal and particularistic relationships with a small number of big indigenous, albeit Sino-Indonesian, capitalists.

The government also had reasonably good mechanisms for weeding out bad investments. For one, the economic technocrats in core macro-economic agencies were allowed to step in whenever bad investments began to threaten macroeconomic stability. Openness to the world economy, at least between 1983 and the financial crisis of 1997, provided other reasonably good signals about bad investments. Finally, the most senior political leaders in Indonesia needed growth to sustain their own legitimacy. Because of this, they were willing to change incentives when investments went bad and growth stalled.

But as we now know, this particular political economy collapsed in the midst of a severe financial cum currency crisis in 1997-98. Since then, three successive governments have been struggling to replace the over-centralized and discredited New Order state along with its equally discredited and highly interventionist economic policies with a more democratic, decentralized and more market-oriented political economy of accumulation and growth. This has not proved easy to do and, so far, governments have been more successful at democratization and decentralization than they have been at building a more market-oriented economy. Surprisingly, Indonesia's transition to democracy has been remarkably smooth. ${ }^{70}$ Relatively free elections in 1999 (Deuster, 2002: 6), a series of constitutional reforms that culminated with provisions for direct election of the president and vice president and the creation of a bicameral legislature (Malley, 2003: 137-138), and the presidential election of Megawati Sukarnoputri appear to have hastened the transition to what may well become stable democratic rule. ${ }^{71}$ The government's 'big bang' decentralization, which

\footnotetext{
${ }^{70}$ A tense struggle between the president and the parliament emerged during the Wahid government (Dick, 2001: 710) but politics has notably improved since Megawati became president (Athukorala, 2002: 142).

${ }^{71}$ As Athukorala (2002: 142) says the spell of relative political tranquility under Megawati has made it possible for her cabinet to move ahead, albeit slowly, on the economic reform agenda.
} 
radically transformed the power relationship between provincial governments and the central government, has been equally smooth. ${ }^{72}$

While both transitions redressed important power imbalances in the old New Order state, each has created serious economic problems for the president and the central government. Because the president's party only controls about one-third of the seats in parliament, she has been forced to form a weak multi-party coalition government that includes some of those who earlier denied her the presidency (Malley, 2003: 136). As experience with democratization in neighboring Thailand attests, weak multi-party coalition governments are often unable to enact tough economic reforms that harm the interests of one or more minor parties in the governing coalition because of fear that one or more of these minor parties will defect bringing the government down. ${ }^{73}$ By itself, this may well explain why progress in the government's microeconomic reform program is so slow. ${ }^{74}$ But to make matters worse, democratization in Indonesia, as in Thailand, has been accompanied by a new and more virulent breed of corruption. With democratization, Suharto's monopoly control of corruption networks has fragmented into a large number of competing corruption networks centered in the legislature (Pangestu and Goeltom, 2001: 299 and Athukorala, 2002: 143), the conglomerates (Dick, 2001: 13), and several important government agencies such as the judiciary (Malley, 2003: 143-144), the central bank (Athukorala, 2002: 143-144) and the customs office (Athukorola, 2002: 144). There is growing evidence that these new corruption networks are undermining both the economic reform program and investor confidence. ${ }^{75}$ And there is little evidence that these new corruption networks are as likely to be as investment and growth enhancing as the corruption network extant during the Suharto era. ${ }^{76}$

\footnotetext{
${ }^{72}$ By mid-2002, the central government had successfully transferred 2 million central government employees to local government (Athukorala, 2002: 146), and as Deuster (2002: 9-10) says, local government expenditures rose from $13 \%$ to $35 \%$ of total government expenditures while major breakdowns were avoided and local government operations were maintained.

${ }^{73}$ In Thailand, democratization led to a proliferation of political parties and fragile multiparty governments with slim parliamentary majorities. As a consequence, there has been little unity in government and almost no cohesion around policy issues. Hicken (1998 and 1999) and MacIntyre (2001: 86) have argued that this institutional structure favors government delay of important policy decisions and under provision of public goods.

${ }^{74}$ For discussion of this problem see Malley (2003: 135-136).

${ }^{75}$ For example, members in the DPR and local business leaders opposed the sale by IBRA of oil palm plantations to a Malaysian firm under the pretext that foreigners should not be allowed to buy these Indonesian assets even though the bid of the Malaysian company was 70\% above the next highest bid (Pangestu and Goeltom, 2001: 147).

${ }^{76}$ Corruption in the customs service has become so bad that most industry associations and foreign chambers of commerce have pressed the government to reduce it (Athukorala, 2002: 144).
} 
Decentralization of government has created a different, but no less formidable, set of problems for economic reformers. On the one hand, newly strengthened local governments have introduced a number of highly questionable levies, such as taxes on the transport of goods through a local jurisdiction, to raise revenues. ${ }^{77}$ Local governments have also interposed themselves, sometimes with near disastrous consequences, into negotiations between the central government and foreign firms. ${ }^{78}$ To make matters worse, local control over enforced minimum wages has been followed by very rapid rises in minimum wages ${ }^{79}$ so that they threaten both the country's labor intensive industries ${ }^{80}$ and employment growth ${ }^{81}$. This has led one analyst to suggest that Indonesia may be in danger of going the way of a number of the Latin American economies that sometime ago locked themselves into high wage policy straitjackets (Manning as quoted in Deuster, 2002: 14).

The major economic consequences of the post-Suharto democratization and decentralization in Indonesia have been the rise of populism ${ }^{82}$, the spread of corruption, significant declines in

\footnotetext{
${ }^{77}$ Truckers delivering goods from North Sumatra to Jakarta are changed tolls based on weight of the truck at 16 weigh stations along the road and truckers delivering oranges to Jakarta from North Sumatra are paying charges averaging between $2 \%$ and $7 \%$ of farm-gate value of their produce (Siregar, 2001: 300).

${ }^{78}$ Local governments in West Sumatra and South Sulawesi blocked the sale of a large cement company (PT Gresek Cement) to CEMEX, a Mexican cement conglomerate, by demanding that units of the company operating within their jurisdiction be exempt from the sale (Siregar, 2001: 11). The government of East Kalimantan recently filed a corruption compliant against a multinational coal company (PT Kaltim Prima Coal or KPC) because it had not finalized sale of $51 \%$ of its assets to a local buyer as required by a 1982 investment agreement with the central government. Since the central government could not afford to buy the $51 \%$ share, the government of East Kalimantan found an alternate buyer that it tired to force KPC to sell to raising expropriation fears within KPC (Athukorala, 2002: 147).

${ }^{79}$ Large increases in minimum wages were granted in a number of provinces in 2000 and 2001 pushing the value of the minimum wage to pre-crisis levels (Deuster, 2002: 13). Additional increases in Jakarta and the surrounding areas led an organization of employers to instruct its members not to pay the new minimum wage and this led the Minister of Manpower and Co-operatives to warn employers about their 'New Order' attitudes (Deuster, 2002:13).

${ }^{80}$ As of December 2002, the garments sector has not recovered from a sharp decline in the last half of 2001 and footwear was facing a major problem following the closure of factories by Nike and Reebok ((Alisjahbana and Manning, 2002: 293).

${ }^{81}$ Between 1996 and 2001, the number of new manufacturing jobs in large and medium firms hardly grew at all (Alisjahbana and Manning2002: 298).

${ }^{82}$ Populism in post-Suharto Indonesia takes three forms. On the one hand, it has been used to justify large increases in the minimum wage such as when a recent labor expert advised the government that the large increases in the minimum wage reflect nothing more than workers catching up with the productivity gains experienced in the 1980s when the economy was booming (Deuster, 2002: 14). But its is also used to slow the sale of industrial assets to foreigners at distressed prices (Redway, 2002: 246) or to sell them to anyone in the Indonesian elite who can afford to buy them because such persons are suspect of fronting for former owners who are thought to be Suharto cronies (Redway, 2002: 244).
} 
foreign and domestic investors' confidence ${ }^{83}$ and the creation of a weak state that is either unable or unwilling to make the hard decisions to restructure the economy. Although successive governments have been more or less able to maintain macroeconomic stability, most microeconomic reforms remain stalled. The banking system is largely owned by the government and has only limited ability to make loans. ${ }^{84}$ Privitization has been extremely limited and the Indonesian Bank Restructuring Agency (IBRA), the agency responsible for restructuring the financial and industrial sectors of the economy, has largely failed (Redway, 2002: 243). The government's new competition policy or market opening polices, designed to eliminate the barriers to competition in the old New Order economic model, appear to be guided by concern for equity (protecting small business) rather than in ensuring a competitive process (Wie, 2002: 340). And there has been significant backsliding in agricultural trade liberalization. Import of cloves and raw sugar, which are domestically processed, has been limited to registered producers in violation of an MOU with the IMF (Alisjahbana and Manning, 2002: 294). The import of rice and wheat flour have been moved from the 'green' to a more intrusive 'red' customs lane; anti-dumping duties have been proposed for wheat flour, and export taxes have been proposed for cocoa (Alisjahbana and Manning, 2002: 295). This combination of inaction and backsliding has led several analysts to wonder whether Indonesia will settle into a Philippines like development model of slow growth with small changes in living standards (Alisjahbana and Manning, 2002: 302).

What lessons can be drawn from this particular historical experience with high-speed and shared economic and industrial growth followed by collapse and slow growth? Four are likely to be important. To begin with, during the New Order, Suharto was extremely successful in integrating his commitment to economic and industrial development with his domestic political objectives. Without this, it is doubtful that Indonesia would have made the transition to high-speed growth. Second, the model he used to do so, paraphrasing Rodrik (2002), suggests that the transition to highspeed growth was sparked by a rather narrow range of policy and institutional reforms. The government never adopted anything like the overly ambitious Washington policy consensus reforms. In fact, it was much more interventionist than that model permits. This suggests that the

\footnotetext{
${ }^{83}$ There are numerous instances of this, but one of the most visible has been the Dharmala-Manulife case where a disgruntled domestic joint venture partner, Dharmala, used the courts to try and extort payments from its foreign joint venture partner, Manulife - a Canadian insurance company (Athukorala, 2002: 145).

${ }^{84}$ The government owns $77 \%$ of the total assets of commercial banks (Deuster, 2002: 26), average loan to deposit ratios are low and the percentage of non-performing loans high (Deuster, 2002: 27).
} 
conditions necessary for a transition to high-speed growth may be less onerous than one might think. Stable macro policies mattered in Indonesia. Security of property rights also mattered. Providing incentives to 'incite' domestic farmers and entrepreneurs to invest was equally important. The government also found ways to sustain growth and weed out bad investments. Finally, Suharto's recognition of the importance of growth and development to his own legitimacy increased the government's ability and resiliency to respond to both external shocks and to a slowing of economic growth.

The second important lesson is that the key elements of this model are highly country specific and are not likely to travel well. As I have argued, elsewhere (Rock, 2002), Indonesia's rice price stabilization policies grew out of its colonial experience. As Timmer (1993 and 1996) has demonstrated rice price stabilization was also peculiarly East Asian. The experiences with commodity stabilization schemes elsewhere in the developing world are decidedly much less promising. The government's subsidies for modern agricultural inputs and its very large investments in primary education depended on the oil boom and a commitment to shared growth. Most governments lack both such commitment and such opportunities and those that have had the luxury of the latter, such as Nigeria, rarely used their windfalls for developmental purposes. Indonesia's success in family planning depended on, among other things, a more secular version of Islam. Most of the rest of the developing world probably faces more serious religious opposition to family planning than the government of Indonesia. Indonesia also discovered a unique way to provide indigenous entrepreneurs with security of property rights. This grew out of relationships between the military and cukong entrepreneurs during Indonesia's independence struggle after World War II and the government's failure to successfully promote the growth of pribumi capitalists. But it took time before Suharto and the military recognized that, by providing security of property rights to these firms, they could use Chinese capital as their financiers (Campos and Root, 1996: 132). Even the government's commitment to macro-economic stability may not travel well. Suharto's commitment to it grew out of his experience with hyperinflation, seminars held at the University of Indonesia in the early days of his rule (Bresnan, 1993: 60-63), and on the ability of the macroeconomic technocrats to help him when growth slowed (Bresnan, 1993: chapter 7 and 10).

The third important lesson is that the government of Indonesia never developed or followed a well-defined blueprint, as exemplified in, for example, the Washington consensus. Instead 
political leaders proceeded pragmatically and, for the most part, on a more or less non-ideological trail and error basis. One final lesson deserves mention. Assembling a political economy of accumulation and growth that also serves the political needs of governing elites is not easy to do. It took time and numerous mistakes before Suharto and his New Order government figured out how to do this. As the experiences in much of the rest of the developing world and in the three postSuharto governments demonstrate, it is much easier and more common for governments to adopt 'development polices' that serve political functions rather than developmental ones. Given this, it remains to be seen whether a more democratic and decentralized government in Indonesia can respond to this difficult challenge by adopting policies that successfully promote a more democratic, decentralized and more prosperous Indonesia. 


\section{References}

Alisjahbana, A. S. and Manning, C. (2002) "Survey of Recent Developments" Bulletin of Indonesian Economic Studies. 38 (3): 277-305.

Aswicahyono, H., Hill, H. and Basri, M.C. (2000). "How Not to Industrialize: Indonesia's Automotive Industry”. Bulletin of Indonesian Economic Studies. 36 (1): 209-241.

Athukorala, P. (2002) "Survey of Recent Developments". Bulletin of Indonesian Economic Studies. 38 (2): 141-162.

Barr, C. M. (1998) "Bob Hasan, the Rise of Apkindo, and the Shifting Dynamics of Control in Indonesia's Timber Sector” Indonesia. 65: 1-36.

Booth, A. (2000) "Poverty and Inequality in the Soeharto Era: An Assessment". Bulletin of Indonesian Economic Studies. 36 (1) April: 73-104.

Booth, A. (1999) "Initial Conditions and Miraculous Growth: Why is Southeast Asia Different from Taiwan and South Korea?” World Development, 27 (2): 301-321.

Booth, A. (1989) "Indonesia's Agricultural Development in Comparative Perspective". World Development. 17 (8), 1235-1254.

Campos, J.E., Root, H.L. (1966) The Key to the Asian Miracle: Making Shared-Growth Credible. Brookings Institution, Washington, D.C.

Chalmers, I. and Hadiz, V. R. eds. (1996) The Politics of Economic Development in Indonesia Routledge, London.

Chenery, H. (1979) Structural Change and Development Policy. Oxford University Press, New York.

Crouch, H. (1978) "Patrimonialism and Military Rule in Indonesia". World Politics. 31 (4), 571587.

Dehanini, S. (2000) Indonesia: Strategy for Manufacturing Competitiveness. Vol. II. Main Report. UNIDO, UNDP/UNIDO Project No. NC/INS/99/004. November.

Deuster, P. R. (2002) "Survey of Recent Developments". Bulletin of Indonesian Economic Studies. 38 (1): 5-37.

Dick, H. (2001) "Survey of Recent Developments". Bulletin of Indonesian Economic Studies. 37 (1): 7-41. 
Duflo, E. (2001) "Schooling and the Labor Market: Consequences of School Construction in Indonesia". American Economic Review. 91 (4) September: 795-813.

Elson, R. (2001) Suharto: A Political Biography. Cambridge: Cambridge University Press.

Geertz, C. (1963) Agricultural Involution. University of California Press, Berkeley.

Gillis, M. (1988) "Indonesia: Public Policies, Resource Management and the Tropical Forest". In Public Policies and the Misuse of Forest Resources, eds. R. Repetto and M. Gillis, pp. 43-113. Cambridge University Press, Cambridge.

Gillis, M. 1984. "Episodes of Indonesian Economic Growth". In World Economic Growth, ed. A.C. Harberger, pp. 231-264. International Center on Economic Growth, San Francisco:

Glassburner, B. (1978a) "Political Economy and the Soeharto Regime". Bulletin of Indonesian Economic Studies. 14 (3), 24-51.

Glassburner, B. (1978b). "Indonesia's New Economic Policy and Its Sociopolitical Implications". In Political Power and Communication in Indonesia, pp. 137-140. ed. K.D. Jackson and L. Pye. University of California Press, Berkeley.

Hamilton-Hart, N. (2001) "Anti-Corruption Strategies in Indonesia" Bulletin of indonesian Economic Studies. 37 (1): 65-82.

Higgins, B. (1968) Economic Development. Second Edition. W. W. Norton, New York.

Hill, H. (1996a) The Indonesian Economy Since 1966. Cambridge University Press, Cambridge, U.K.

Hill, H. (1996b) "Indonesia's Industrial Policy and Performance: Orthodoxy Vindicated". Economic Development and Culture Change. 45 (October), 146-174.

Hull, T. H. (1994) "Fertility Decline in the New Order Period: The Evolution of Population Policy" in Hill, H. (ed.) Indonesia's New Order: The Dynamics of Socio-Economic Transformation. Honolulu: University of Hawaii Press. 123-145.

Jackson, K. D. (1978) "Bureaucratic Polity: A Theoretical Framework for Analysis of Power and Communication in Indonesia". In Political Power and Communication in Indonesia, pp. 3-22. ed. K.D. Jackson and L. Pye. University of California Press, Berkeley.

Jones, G. W. and Hagul, P. (2001) "Schooling in Indonesia: Crisis-Related and Longer Term Issues" Bulletin of Indonesian Economic Studies. 37 (2): 207-231.

Kang, D. C. (2002) Crony Capitalism. Cambridge: Cambridge University Press. 
Kaufmann, D., Kraay, A. and Loido-Lobaton, P, (1999) Governance Matters. World Bank Policy Research Department Working Paper No. 2196. Washington, D.C.: World Bank.

Khan, M. H. and Jomo, K.S.(eds.) (2000) Rents, Rent-Seeking and Economic Development: Theory and Evidence from Asia Cambridge: Cambridge University Press.

Khan, M. H. (1996) "The Efficiency Implications of Corruption". Journal of International Development. 8 (5): 683-696.

King, D. Y. (2000) “Corruption In Indonesia: A Curable Cancer” Journal of International Affairs. 53 (2): 603-624.

King, D. Y. (1995/96) "Bureaucracy and Implementation of Complex Tasks in rapidly Developing States: Evidence from Indonesia". Studies in Comparative International Development. 30 (4) Winter: 78-92.

Knack, S. and Keefer, P. (1995) "Institutions and Economic Performance: Cross Country Tests Using Alternative Institutional Measures” Economics and Politics. 7 (3) 207-227.

Krugman,P.(1998)“What Happened to Asia?”, http://web.mit.edu/krugman/www/DISINTER.html.

Liddle, R. W. (1998) “Indonesia: Soeharto’s Tightening Grip” in Diamond, L. and Plattner, M. F. (eds.) Democracy in East Asia. Baltimore: Johns Hopkins University Press, 199-216.

Liddle, R. W. (1991) "The Relative Autonomy of the Third World Politician: Soeharto and Indonesian Development in Comparative Perspective". International Studies Quarterly. 35, 403427.

Liddle, R. W. (1985) “Soeharto's Indonesia: Personal Rule and Political Institutions” Pacific Affairs 58 (1): 68-90.

Malley, M. S. (2003) “Indonesia in 2002: The Rising Costs of Inaction” Asian Survey. 43 (1): 135146.

McCawley, P. (1982) "The Economics of Ekonomi Pancasila". Bulletin of Indonesian Economic Studies. 18 (1), 102-109.

Mackie, J. and MacIntyre, A. (1994) "Politics" In Indonesia's New Order: The Dynamics of SocioEconomic Transformation, pp. 1-53. ed. H. Hill, Allen and Unwin, Sydney.

MacIntyre, A. (2000) "Funny Money: Fiscal Policy, Rent-Seeking and Economic performance in Indonesia" in Khan, M. H. and Jomo, K.S.(eds.) Rents, Rent-Seeking and Economic Development: Theory and Evidence from Asia Cambridge: Cambridge University Press. pp. 248-273. 
MacIntyre, A. (1994) "Power, Prosperity, and Patrimonialism: Business and Government in Indonesia," In Business and Government in Industrializing Asia, ed. A. MacIntyre, pp. 244-267. Cornell University Press, Ithaca.

MacIntyre, A. (1993) "The Politics of Finance in Indonesia: Command, Confusion, and Competition". In The Politics of Finance in Developing Countries, pp. 123-164. eds. S. Haggard, C.H. Lee, and S. Maxfield. Cornell University Press, Ithaca.

Mellington, N. and Cameron, L. (1999) "Female Education and Child Mortality in Indonesia". Bulletin of Indonesian Economic Studies. 35 (3) December: 115-144.

Pabottingi, M., (1995) “Indonesia” Historicizing The New Order's Legitimacy Delimma”, in Alagappa, M. (ed.) Political Legitimacy in Southeast Asia. Stanford University Press, Stanford, pp. 224-256.

Pangaribuan, R. (1995) The Indonesian State Secretariat: 1945-1993. Asia Research Center on Social and Political Change. Murdoch University: Western Australia.

Pangestu, M. and Goeltom, M. S. (2001) "Survey of Recent Developments". Bulletin of Indonesian Economic Studies. 37 (2): 141-171.

Pincus, J. and Ramli, R. (1998) "Indonesia: From Showcase to Basket Case" Cambridge Journal of Economics. 22: 723-734.

Repetto, R. (1988) The Forest for the Trees: Government Policies and Misuse of Forest Resources. World Resources Institute, Washington, D.C.

Robertson-Snape, F. (1999) "Corruption, Collusion and Nepotism in Indonesia". Third World Quarterly. 20 (3): 589-602.

Robison, R. (1992) "Industrialization and the Economic and Political Development of Capital: The Case of Indonesia". In Mcvey, R. (ed.) Southeast Asian Capitalists. Ithaca: Cornell Southeast Asia Program.

Robison, R. (1986) Indonesia and the Rise of Capital. Allen and Unwin, Sydney.

Rock, M. T. (2002) "Exploring the Impact of Selective Interventions in Agriculture on the Growth of Manufactures in Indonesia, Malaysia, and Thailand", Journal of International Development. 14: 485-510.

Rock, M. T. (1999) "Reassessing the Effectiveness of Industrial Policy in Indonesia: Can the Neoliberals be Wrong?" World Development. 27 (4): 691-704.

Rock, M. T. and Bonnett, H. (2003) "The Comparative Politics of Corruption: Accounting for Corruption in Growth Accounting Studies". Manuscript under review by World Development. 
Rodrik, D. (2002) "Keynote Speech at Alternatives to Neo-liberalism Conference", Carnegie Endowment for International Peace, Washington, D.C. May 23.

Redway, J. (2002) "An Assessment of the Asset Management Company Model in the Reform of Indonesia's Banking Sector”. Bulletin of Indonesian Economic Studies. 38 (2): 241-250.

Sato, Y. (1996) "The Astra Group: A Pioneer of Modernization in Indonesia". The Developing Economies. 34 (3), 247-280.

Sato, Y. (1993) "The Salim Group in Indonesia: The Development and Behavior of the Largest Conglomerate in Southeast Asia". The Developing Economies. 31 (4), 408-441.

Shleifer, A. and Vishny, R. W. (1993) “Corruption” The Quarterly Journal of Economics. 108 (3).

Siregar, R. Y. (2001) "Survey of Recent Developments" Bulletin of Indonesian Economic Studies. 37 (3): 277-303.

Sunderlin, W.D. (1999) "Between Danger and Opportunity: Indonesia's Forests in an Era of Economic Crisis and Political Change”. www.cgiar/research/projects/project1/crisis1.html.

Szirmai, A. (1994) "Real Output and Labor Productivity in Indonesian Manufacturing, 1975-90". Bulletin of Indonesian Economic Studies. 30 (2), 49-90.

Timmer, M. P. (1999) "Indonesia's Ascent on the Technology Ladder: Capital Stock and Total Factor Productivity Growth in Manufacturing: 1975-95”. Bulletin of Indonesian Economic Studies. 31 (1): 75-97.

Timmer, P. (1996) "Does Bulog Stabilize Rice Prices? Should it Try?". Bulletin of Indonesian Economic Studies. 32 (2), 45-74.

Timmer, C.P. (1993) "Rural Bias in the East and Southeast Asian Rice Economies". Journal of Development Studies. 149-176.

Timmer, C.P. (1989) "Agricultural Prices and Stabilization Policy". Development Discussion Paper No. 290 AFP. Harvard Institute for International Development, Cambridge, Mass.

Timmer, C.P. (1975) "The Political Economy of Rice in Asia: Indonesia". Food Research Institute Studies. 14 (3), 197-231.

Transparency International (2002) "Historical Comparisons" Internet Center for Corruption Research. Accessed on June 8, 2002. http://www.gwdg.de/ uwvw/histor.htm. 
Warwick, D. P. (1986) "The Indonesian Family Planning Program: Government Influence and Client Choice". Population and Development Review. 12 (3) (September): 453-490.

Wedeman, A. (1997) "Looters, Rent-Scrappers, and Dividend-Collectors: Corruption and Growth in Zaire, South Korea and the Philippines", Journal of Developing Areas. 31 (Summer): 457-478.

Winters, J. A. (1996) Power in Motion: Capital Mobility and the Indonesian State. Ithaca: Cornell University Press.

Wie, T. K. (2002) "Competition Policy in Indonesia and the New Anti-Monopoly and Fair Competition Law". Bulletin of Indonesian Economic Studies. 38 (3): 331-342.

Woo, W. T., Glassburner, B. and Nasution, A. (1994) Macroeconomic Policies, Crises, and Long Term Growth in Indonesia, 1965-90. World Bank, Washington, D.C.

World Bank (2000) World Development Indicators, 2000. Washington, D.C.: World Bank, CD-ROM.

World Bank (1998) Education in Indonesia: From Crisis to Recovery. Report No. 16369-IND. Education Sector Unit. East Asia and Pacific Regional Office. Washington, D.C. : World Bank.

World Bank. (1993) The East Asian Miracle. New York: Oxford University Press. 


\section{DAVIDSON INSTITUTE WORKING PAPER SERIES - Most Recent Papers}

The entire Working Paper Series may be downloaded free of charge at: www.wdi.bus.umich.edu

CURRENT AS OF $1 / 13 / 04$

\begin{tabular}{|c|c|c|}
\hline Publication & Authors & Date \\
\hline $\begin{array}{l}\text { No. 638: The Politics of Economic Reform in Thailand: Crisis and } \\
\text { Compromise }\end{array}$ & Allen Hicken & Jan. 2004 \\
\hline $\begin{array}{l}\text { No. 637: How Much Restructuring did the Transition Countries } \\
\text { Experience? Evidence from Quality of their Exports }\end{array}$ & Yener Kandogan & Jan. 2004 \\
\hline $\begin{array}{l}\text { No. 636: Estimating the Size and Growth of Unrecorded Economic } \\
\text { Activity in Transition Countries: A Re-Evaluation of Eclectric } \\
\text { Consumption Method Estimates and their Implications }\end{array}$ & Edgar L. Feige and Ivana Urban & Dec. 2003 \\
\hline No. 635: Measuring the Value Added by Money & Vlad Ivanenko & Nov. 2003 \\
\hline $\begin{array}{l}\text { No. 634: Sensitivity of the Exporting Economy on the External Shocks: } \\
\text { Evidence from Slovene Firms }\end{array}$ & $\begin{array}{l}\text { Janez Prašnikar, Velimir Bole, } \\
\text { Aleš Ahcan and Matjaž Koman }\end{array}$ & Nov. 2003 \\
\hline $\begin{array}{l}\text { No. 633: Reputation Flows: Contractual Disputes and the Channels for } \\
\text { Inter-firm Communication }\end{array}$ & William Pyle & Nov. 2003 \\
\hline $\begin{array}{l}\text { No. 632: The Politics of Development Policy and Development Policy } \\
\text { Reform in New Order Indonesia }\end{array}$ & Michael T. Rock & Nov. 2003 \\
\hline $\begin{array}{l}\text { No. 631: The Reorientation of Transition Countries' Exports: } \\
\text { Changes in Quantity, Quality and Variety }\end{array}$ & Yener Kandogan & Nov. 2003 \\
\hline $\begin{array}{l}\text { No. 630: Inequality of Outcomes and Inequality of Opportunities in } \\
\text { Brazil }\end{array}$ & $\begin{array}{l}\text { François Bourguignon, Francisco } \\
\text { H.G. Ferreira and Marta } \\
\text { Menéndez }\end{array}$ & Nov. 2003 \\
\hline No. 629: Job Search Behavior of Unemployed in Russia & Natalia Smirnova & Nov. 2003 \\
\hline $\begin{array}{l}\text { No. 628: How has Economic Restructuring Affected China's Urban } \\
\text { Workers? }\end{array}$ & John Giles, Albert Park, Feng Cai & Oct. 2003 \\
\hline No. 627: The Life Cycle of Government Ownership & Jiahua Che & Oct. 2003 \\
\hline $\begin{array}{l}\text { No. 626: Blocked Transition And Post-Socialist Transformation: Siberia } \\
\text { in the Nineties }\end{array}$ & Silvano Bolcic & Oct. 2003 \\
\hline $\begin{array}{l}\text { No. 625: Generalizing the Causal Effect of Fertility on Female Labor } \\
\text { Supply }\end{array}$ & $\begin{array}{l}\text { Guillermo Cruces and Sebastian } \\
\text { Galiani }\end{array}$ & Oct. 2003 \\
\hline $\begin{array}{l}\text { No. 624: The Allocation and Monitoring Role of Capital Markets: } \\
\text { Theory and International Evidence }\end{array}$ & Solomon Tadesse & Oct. 2003 \\
\hline No. 623: Firm-Specific Variation and Openness in Emerging Markets & $\begin{array}{l}\text { Kan Li, Randall Morck, Fan Yang } \\
\text { and Bernard Yeung }\end{array}$ & Oct. 2003 \\
\hline $\begin{array}{l}\text { No. 622: Exchange Rate Regimes and Volatility: Comparison of the } \\
\text { Snake and Visegrad }\end{array}$ & $\begin{array}{l}\text { Juraj Valachy and Evžen } \\
\text { Kočenda }\end{array}$ & Oct. 2003 \\
\hline $\begin{array}{l}\text { No. 621: Do Market Pressures Induce Economic Efficiency?: The Case } \\
\text { of Slovenian Manufacturing, 1994-2001 }\end{array}$ & $\begin{array}{l}\text { Peter F. Orazem and Milan } \\
\text { Vodopivec }\end{array}$ & Oct. 2003 \\
\hline $\begin{array}{l}\text { No. 620: Compensating Differentials in Emerging Labor and Housing } \\
\text { Markets: Estimates of Quality of Life in Russian Cities }\end{array}$ & $\begin{array}{l}\text { Mark C. Berger, Glenn C. } \\
\text { Blomquist and Klara Sabirianova } \\
\text { Peter }\end{array}$ & Oct. 2003 \\
\hline $\begin{array}{l}\text { No. 619: Are Foreign Banks Bad for Development Even If They Are } \\
\text { Efficient? Evidence from the Indian Banking Sector }\end{array}$ & $\begin{array}{l}\text { Sumon Bhaumik and Jenifer } \\
\text { Piesse }\end{array}$ & Oct. 2003 \\
\hline No. 618: The Echo of Job Displacement & $\begin{array}{l}\text { Marcus Eliason and Donald } \\
\text { Storrie }\end{array}$ & Oct. 2003 \\
\hline No. 617: Deposit Insurance During Accession EU Accession & $\begin{array}{l}\text { Nikolay Nenovsky and Kalina } \\
\text { Dimitrova }\end{array}$ & Oct. 2003 \\
\hline $\begin{array}{l}\text { No. 616: Skill-Biased Transition: The Role of Markets, Institutions, and } \\
\text { Technological Change }\end{array}$ & Klara Sabirianova Peter & Oct. 2003 \\
\hline $\begin{array}{l}\text { No. 615: Initial Conditions, Institutional Dynamics and Economic } \\
\text { Performance: Evidence from the American States }\end{array}$ & Daniel Berkowitz and Karen Clay & Sept. 2003 \\
\hline $\begin{array}{l}\text { No. 614: Labor Market Dynamics and Wage Losses of Displaced } \\
\text { Workers in France and the United States }\end{array}$ & Arnaud Lefranc & Sept. 2003 \\
\hline No. 613: Firm Size Distribution and EPL in Italy & $\begin{array}{l}\text { Fabiano Schivardi and Roberto } \\
\text { Torrini }\end{array}$ & Sept. 2003 \\
\hline
\end{tabular}

